\title{
A mulher ausente: a presença de Maria Velluti (1827-1891) no teatro brasileiro
}

The absent woman: the presence of Maria Velluti (1827-1891) in Brazilian theatre

Andrea Carvalho Stark ${ }^{1}$ 


\section{Resumo}

O artigo discorre sobre a carreira da atriz, bailarina, tradutora, dramaturga Maria Velluti (Lisboa, 1827 - Rio de Janeiro, 1891) no teatro brasileiro do século XIX. Como atriz, ela foi protagonista de obras de autores brasileiros do período realista, especialmente as primeiras peças de José de Alencar. Foi também a criadora do Teatro Ginásio Dramático, único espaço que concentrou diversas estreias de autores nacionais nos oitocentos. O objetivo é demonstrar que Velluti exerceu um papel relevante no contexto do teatro brasileiro do século XIX, apesar do esquecimento que a história legou a seu nome.

Palavras-chave: Século XIX; atrizes; realismo; história do teatro

\section{Abstract}

This article looks at the work of actress, ballerina, playwright and translator Maria Velluti (Lisbon, 1827-Rio de Janeiro, 1891) in the 19th century Brazilian theatre. As an actress, she had been the protagonist of Brazilian plays from the realist period, especially the first ones composed by José de Alencar. She was also the creator of the Dramatic Gymnasium Theatre, the only space that concentrated diverse premieres of Brazilian playwrights during the 19th century. The goal is to demonstrate that Velluti had played a relevant role in the 19th century Brazilian theatre, despite the forgetfulness that history had bequeathed to her.

Keywords: 19th century; actresses; realism; theatre history

E-ISSN: 2358.6958 
No dia 30 de maio de 1881, o jornal Gazeta da Tarde do Rio de Janeiro publicou em sua capa um breve texto noticiando a missa pelo falecimento da "senhora Júlia de Menezes", jovem esposa do diretor do jornal, o jornalista Ferreira de Menezes. A missa solene realizada na igreja de São Francisco, no largo de mesmo nome, centro do Rio de Janeiro, contou com uma orquestra composta pelos "melhores professores do Teatro Pedro II", no total de vinte e dois músicos, que tocou duas marchas fúnebres. Estavam presentes personalidades da política, da literatura, do teatro e das artes plásticas - citados com reverência como forma de enaltecer a importância do espaço social que na missa se representava. Eram coronéis, viscondes, doutores, senadores, engenheiros, comendadores, escritores, "artistas dramáticos" e músicos, ou seja, nomes pertencentes às diversas esferas sociais daquele tempo de Segundo Reinado foram prestigiar a família - o viúvo e seus dois filhos pequenos - em seu momento de luto.

Alguns dos nomes citados que se relacionam ao âmbito político, podemos ainda hoje encontrar nas bibliografias referentes aos oitocentos. Por exemplo, João Evangelista de Negreiros Saião Lobato, visconde de Sabará (1817-1894), nomeado pelo Imperador D. Pedro II como ministro do Supremo Tribunal de Justiça, e, na República, igualmente nomeado pelo marechal Deodoro da Fonseca como ministro do Supremo Tribunal Federal. Outro nome de muitos títulos é Antônio Cândido da Cruz Machado (1820-1905), visconde de Serro Frio, advogado que foi vereador, deputado geral, presidente de província, senador do Império do Brasil (1874-1889), juiz de paz, promotor e coronel da Guarda Nacional.

Os nomes citados da literatura são Machado de Assis e Quintino Bocaiúva, cujas obras chegaram até nós. Entre os representantes do teatro, encontramos os atores Mattos e Flávio, nomes muito presentes no teatro da época, mesmo que não sejam identificados os sobrenomes, como era comum nas listagens de elencos. Eles se juntaram a uma única mulher como representante dos "artistas dramáticos" na ocasião, essa com nome e sobrenome, Maria Velluti, uma senhora de 53 anos, já reconhecida como uma das atrizes mais importantes de seu tempo. A história não legou à Maria Velluti o mesmo lugar ao lado de quem esteve com ela na ocasião solene em 1881, apesar de sua reconhecida atuação como artista de teatro.

Se no âmbito da literatura, escritoras de séculos pretéritos são nomes de raro registro hoje, no âmbito do teatro, cuja própria matéria de arte resulta no efêmero, a pesquisa sobre artistas mulheres enfrenta um maior desafio, pois, torna-se mais difícil resgatar sua história e presença quando em seu próprio tempo elas sofreram o legado do esquecimento.

No caso de Maria Velluti, apesar das crônicas, folhetins, notícias e registros de seu trabalho como tradutora, atriz e dramaturga, ainda lemos em um obituário escrito por Artur Azevedo em seu folhetim, sob o pseudônimo "Eloy, o Herói", que ela "era uma mulher ilustre: foi amada por Almeida Garrett, de quem tinha um filho que lhe fartou de dar desgostos" (Diário de Notícias, 19 jul. 1891, p.1), quando ela havia sido a mãe negra escrava de uma peça de José de Alencar, transformando o papel em um dos principais de sua carreira.

Outro apagamento histórico se refere ao seu papel na reestruturação do Teatro São Francisco, que se transformou no Teatro Ginásio, com uma nova proposta. 
Podemos considerar que aquele pequeno teatro se tornou palco de importantes encenações da história do teatro brasileiro, com a iniciativa e colaboração da atriz, tradutora e dramaturga que esteve na gênese desse projeto. Uma mulher de teatro que possivelmente se envolveu na escolha de repertórios, já que atuou como a tradutora de peças encenadas pela nova companhia em seu primeiro momento, moldando um novo público e um modelo seguido por autores brasileiros.

\section{Primeiros anos na Corte}

Maria da Conceição Singer Velluti nasceu em Lisboa em 10 de dezembro de 1827. Iniciou sua carreira como bailarina ainda em sua cidade natal, e como atriz posteriormente, com formação pelo Conservatório Real de Lisboa e atuação no Teatro D. Maria na mesma cidade (O Tempo, 17 jul. 1891, p.1). Velluti desembarcou no porto do Rio de Janeiro em 27 de agosto de 1847, acompanhada por sua irmã, Henriquetta (Jornal do Commercio, 28 ago. 1847, p.4). ${ }^{2}$ Não há registro nesse momento de estar com um filho, o que nos faz supor que talvez ela estivesse grávida ao chegar à cidade, pois, crônicas da época registram que Velluti era mãe de um filho do escritor e dramaturgo português Almeida Garrett (Porto, 1799 - Lisboa, 1854), mentor da atriz no início de sua carreira (O Tempo, 17 jul. 1891, p.1; Diário de Notícias, 19 jul. 1891, p.1). ${ }^{3}$

Não conseguimos referências sobre a vida de Velluti antes de chegar ao Brasil, entretanto, em uma publicação de 1859 do drama $A$ vida de uma atriz, de Auguste Anicet-Bourgeois e Théodore Barrière, traduzido por Velluti, ela escreveu uma dedicatória à Ludovina Soares da Costa, primeira atriz da peça e a quem a tradução foi dedicada, revelando que sua primeira vocação foi de escritora. De uma infância em que "lia e decorava Marilia de Dirceu, e as obras de Malhão", Velluti passou a compor versos e prosas, porém, desistindo perante às criticas e a falta de incentivo:

Com o andar do tempo desiludi-me do maravilhoso, e abracei-me ao romântico: compunha! ... isto é, delirava imaginando lindas fantasias! Mas, quando descia dessas macias e vistosas regiões de ouro e algodão, era com a cabeça estonteada... a vista turba... parecendo-me a realidade feia e asquerosa! Não podendo suportar os tropeções neste mundo de pedras. Felizmente mostrava as minhas produções a entendedores que diziam, sobre a poesia: Está bonito! Mas não está bom... falta-lhe metro. Sobre a prosa a mesma coisa: falta-lhe gramática. "Bem bom! Disse comigo; não pode haver verso sem metro, e mal se admite a prosa sem gramática... estou salva! Guardo as minhas ideias, e não aprendo nem uma, nem outra coisa". Ora, se eu sem metro nem gramática, quase não sentia a terra... com metro e com gramática voava pelas palhas! Renunciei e fiz muito bem. (Anicet-Bourgeois; Barriére, 1859, p.2)

O primeiro trabalho de Velluti na Corte foi como atriz no Teatro São Francisco, com a companhia dramática de João Caetano, na estreia do drama Um pai em 24 de

\footnotetext{
2 Nenhuma referência localizamos sobre essa irmã, além do registro da entrada no porto do Rio de Janeiro.

3 Sobre esse filho com Garrett pouco conseguimos apurar. Segundo Lafayette Silva, Velluti veio para o Brasil, aos 20 anos, após uma desilusão amorosa no relacionamento com o escritor, do qual nasceu um filho que ela criou sozinha no Rio de Janeiro. Esse filho era formado pelo Colégio Pedro II (Correio da Manhã, 13/09/1928, p.4). Em uma crônica, Artur Azevedo cita o filho de Velluti e Garrett que havia tentado suicídio com arma de fogo, e não era a primeira vez (A Notícia, 10-11 nov. 1892, p. 2).
} 
outubro de 1847, que finalizava com uma ária de Martinho Corrêa Vasques ${ }^{4}$ e com a farsa Tudo à estrangeira, compondo o conjunto do espetáculo heterogêneo, conforme era comum nos teatros. No anúncio da peça, a estreia de Velluti obteve destaque: “Representação do drama em três atos Um pai com que fará a sua estreia Sra. Maria Velluti, discípula do Real Conservatório de Lisboa, e recentemente chegada a essa Corte" (Jornal do Commercio, 24 out. 1847, p.4).

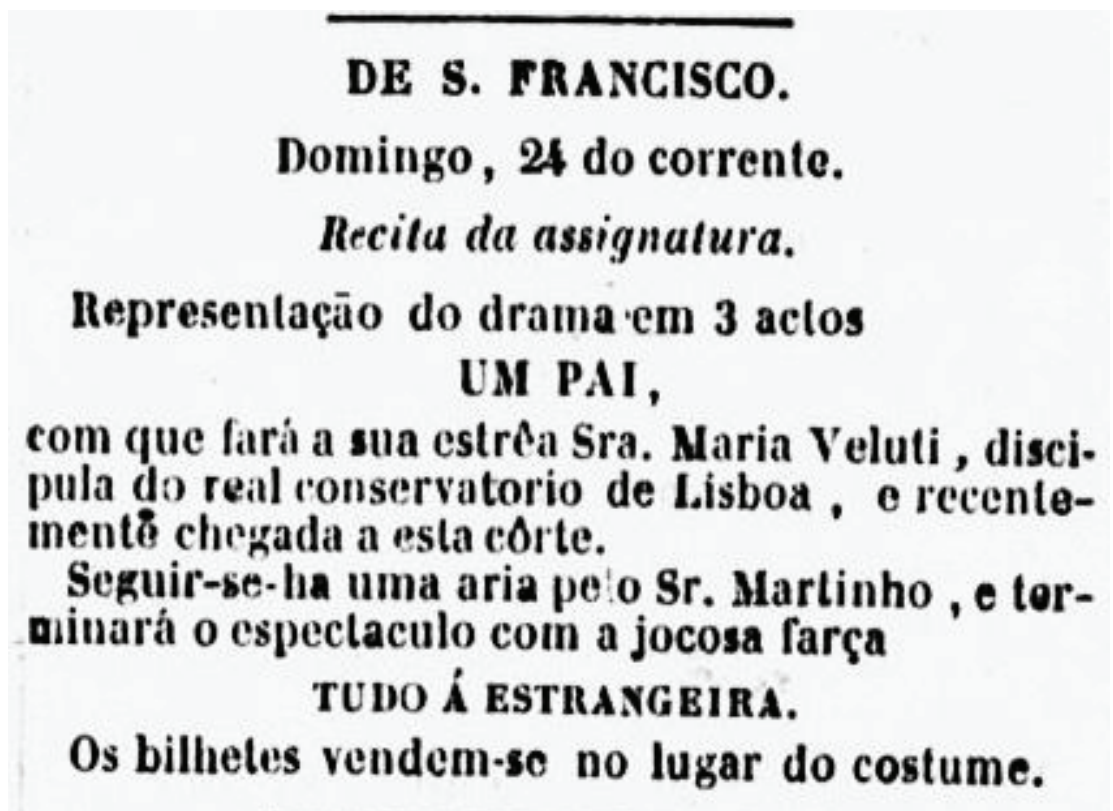

Imagem 1: Anúncio da estreia de Maria Velluti no Rio de Janeiro em 1847. Fonte: Jornal do Commercio, 24 out. 1847, p. 4.

A partir de então, Velluti passou a realizar trabalhos como bailarina e atriz na companhia de João Caetano. A dupla função não era de se estranhar, pois as companhias dramáticas possuíam seu próprio corpo de baile, já que o balé se apresentava nos intervalos ou encerramento dos dramas. Nem todas as atrizes faziam esse trânsito, mas não era incomum ser uma bailarina e uma atriz na mesma companhia, especialmente as mulheres, sanando uma carência dessas profissionais da cena. Como bailarina, Velluti inicialmente integrava o corpo de baile da companhia dramática de João Caetano que já contava com os bailarinos Giuseppe De-Vecchy e Francesco York, ambos também coreógrafos, e as bailarinas Clara Ricciolini e Jesuína Montani. York era anunciado como criador de um balé da ópera La Favorite apresentado com De-Vecchy, Ricciolini, Montani e Velluti em 1848 no Teatro São Francisco, que também foi o palco onde ela se apresentou vestida "em caráter de oficial francês" no balé A Cracovienne (A Cracoviana) (Jornal do Commercio, 20 jul. 1848, p.4; 08 jul. 1848, p.3; 05 jan. 1848, p.4).

\footnotetext{
${ }^{4} \mathrm{O}$ ator cômico, brasileiro e negro, Martinho Corrêa Vasques nasceu em 1822 no Rio de Janeiro. Era irmão mais velho, por parte de mãe, do também ator cômico Francisco Corrêa Vasques.

${ }^{5}$ Cracoviana é uma dança polaca executada aos pares. O Dicionário Aurélio século XXI - Edição digital assim define: "Do francês cracovienne. Dança polonesa viva e alegre, com dois andamentos".
} 


\section{THEAFBOS.}

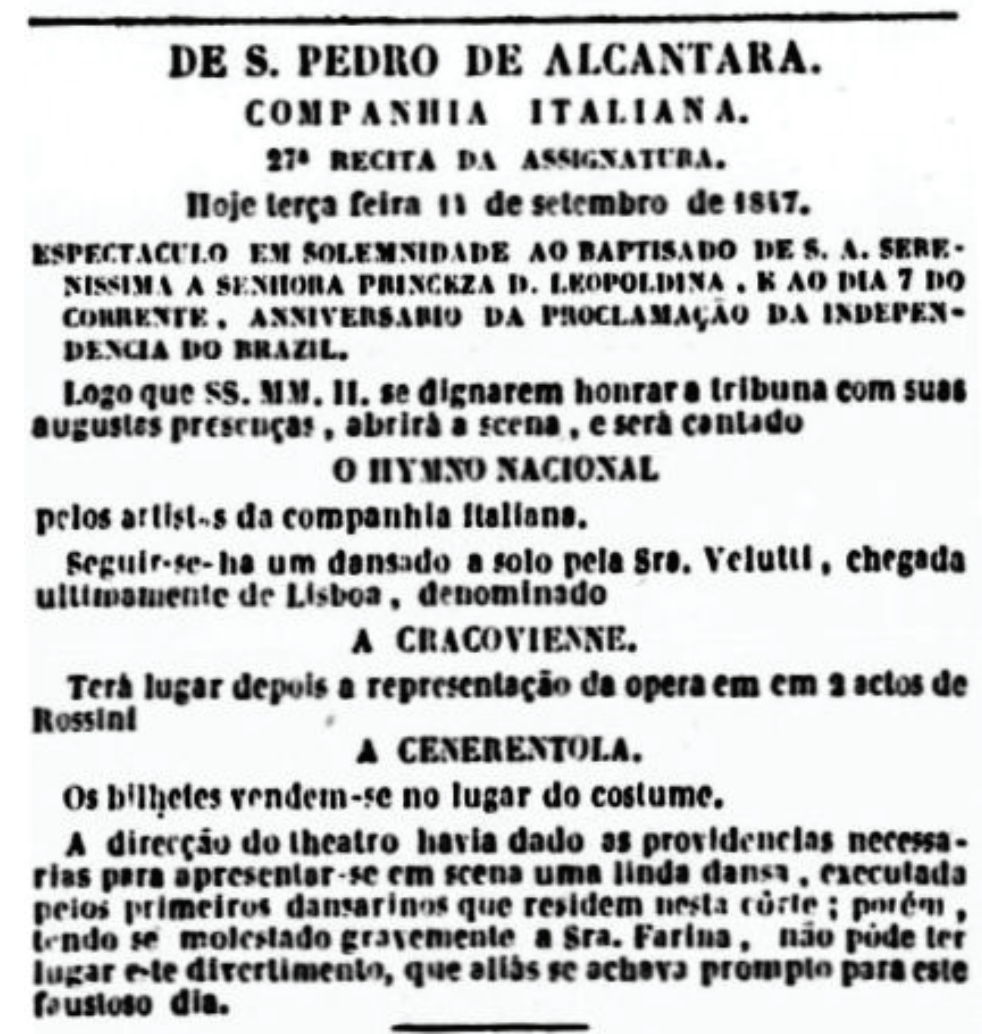

Imagem 2: Anúncio com Velluti dançando A Cracovienne (A Cracoviana) em espetáculo de gala pelo batizado da princesa Leopoldina e pela proclamação da independência, em 11 de set. de 1847, no Teatro São Pedro de Alcântara. Fonte: Jornal do Commercio, 11 set. 1847.

Em seus primeiros meses de Brasil, encontramos os "dançados" de Maria Velluti também nos intervalos dos dramas do Teatro de Santa Teresa, em Niterói, que reproduzia do outro lado da baía o mesmo programa do São Francisco, pois ambos eram dirigidos por João Caetano. Nesse teatro de Niterói, Maria Velluti dançou seu pas de deux com Giuseppe De-Vecchy, As Amazonas, em noite de ópera com o soprano Arthèmise Duval (Jornal do Commercio, 05 jan. 1848, 12 mar. 1848, 25 out. 1848, p.4).

Cerca de um ano após sua estreia com João Caetano, Velluti se transferiu para outra companhia dramática, a de Florindo Joaquim da Silva, que estava ocupando o Teatro São Pedro de Alcântara. Nesse teatro, em setembro de 1848, Velluti estava no elenco de estreia do drama $A$ terrível vingança de uma mulher ou o filho repudiado (Jornal do Commercio, 08 set. 1848, p.4).

A nova década se iniciava e com ela uma mudança de companhias entre o Teatro São Francisco e o Teatro São Pedro de Alcântara - o maior e mais importante teatro da Corte. ${ }^{6}$ João Caetano assumiu a direção do São Pedro e do Teatro São Januário, gerenciados pela mesma sociedade de acionistas, sem deixar o seu Teatro de Santa Teresa, em Niterói. Nesse momento, sua companhia dramática também se apresentava nesses três teatros e, assim, encontramos Velluti com Clara Ricciolini no São Januário, em 1849, dançando uma coreografia composta por York intitulada

\footnotetext{
6 O Teatro São Francisco era localizado na rua de São Francisco, chamada rua do Theatro ainda no século XIX, e era muito próximo ao Teatro São Pedro de Alcântara, localizado na praça da Constituição, atual praça Tiradentes.
} 
Uma bela Caxuxa, antes da farsa que encerrava a noite de estreia de O pobre idiota ou Os subterrâneos de Heylberg, com João Caetano no papel principal (Jornal do Commercio, 16 abr.1849, p.4).

Pouco tempo depois, Velluti se juntaria novamente a Florindo Joaquim da Silva quando o empresário e ator estava com uma companhia no Teatro São Francisco, formada por alguns dissidentes da companhia de João Caetano que criaram essa nova empresa teatral no começo de 1851. Velluti se juntou a esse grupo - composto por Gabriela da Cunha De-Vecchy, Guilherme Orsat, Leonor Orsat Mendes, Clotilde Benedetti, Jesuina Montani - no mesmo ano de sua criação (Almanak, 1852; Andrade, 1967). Nessa nova fase, ela também se apresentou como bailarina, fez $A$ Mazurka com Jesuina Montani e A Scotishe com Jesuina Montani, Leonor Orsat e Guilherme Orsat (Jornal do Commercio, 05 out. 1851, p.4; Correio Mercantil, 11 set. 1851, p.4).

No entanto, parece que a separação de João Caetano não duraria muito tempo, pois, em 1853, Velluti estava se apresentando em espetáculos comuns da programação de assinaturas da companhia do ator-empresário. Além de realizar números de dança solo nos intervalos, ela participou de um espetáculo mais autoral em 01 de maio de 1853, no Teatro São Pedro de Alcântara, quando dançou um papel masculino no balé Os Pescadores, com música de João Victor Ribas e coreografia do bailarino Jules Toussaint ${ }^{7}$ (Jornal do Commercio, 01 maio 1853, p.4). Ainda nesse momento, Velluti integrou o elenco do drama A cisterna arruinada, interpretando três papéis: Luiza (filha de Gonzales), Chefe de Aguasis e Um preto (Jornal do Commercio, 02 ago. 1853, p.3). Além dos dramas, ela também estava ao lado de Martinho Corrêa Vasques nos elencos das comédias curtas em um ato que finalizavam os espetáculos. Com Martinho e Manuel Soares, em 1854, no São Pedro, Velluti fez a farsa Os dois tambores (Jornal do Commercio, 11 maio 1854, p.4). Em 1855, no mesmo teatro, com Clara Ricciolini e Martinho Vasques, Velluti dançou o "jocoso divertimento" que terminava com a "bela" Polka das rosas - um número de canto e dança muito popular, parte de um espetáculo que teve como drama a encenação da tragédia Hamlet, de William Shakespeare, encenada por João Caetano, com o ator como Hamlet e Ludovina Soares da Costa como Gertrudes ${ }^{8}$ (Diário do Rio de Janeiro, 05 fev. 1855, p.4).

Farsa, balé, drama faziam parte da atuação de Maria Velluti nos teatros da Corte em seus primeiros anos de carreira no Brasil, mas a década de 1850 ainda reservaria outra importante realização. A partir de 1855, a carreira de Velluti seria marcada pelo seu engajamento na criação de um novo espaço teatral que a levaria novamente ao lugar que abrigou sua estreia no Brasil. Após ser despedida por João Caetano, a

\footnotetext{
O "divertimento em 1 quadro" Os Pescadores, passava-se em um mar da Itália e finalizou o espetáculo do dia 1 de maio de 1853, que apresentou a comédia em 1 ato Maricota ou os efeitos da educação, um dueto da ópera Norma, com Zecchini e Kastrup, a comédia em 5 atos 0 chapéu de palhinha de Itália ou Os apuros de um noivo. No elenco do balé em um ato, as bailarinas Vaudras (Laura), Clara Ricciolini (Marianna, vizinha de Laura) e Velluti (Fabrigio, pescador); os bailarinos Dias (Giacopo, pai de Laura) e Jules Toussaint (Pietro, pescador). João Victor Ribas, músico e compositor português da cidade do Porto, era maestro da companhia de ópera italiana do teatro São Pedro desde sua estreia em 17 de janeiro de 1844. Jules Toussaint, apesar do nome francês, era nascido no Brasil, sobrinho do bailarino José Maria Tousssaint que atuou entre 1825 e 1832 no mesmo teatro (Zamith, 2011).

8 Esse espetáculo ocorreu no Teatro São Pedro de Alcântara em benefício da bailarina Clara Ricciolini. Uma overture da ópera Nabucodonossor abriu a noite e antecedeu a tragédia de Shakespeare, Hamleto, traduzida por Antonio José de Araújo. Em seguida, a execução da "nova valsa", D. Pedro V, pela orquestra do teatro, "dedicada a S. M. o rei de Portugal", composição de Antonio Xavier da Cruz Lima; Clara Ricciolini, Martinho e Velluti no "jocoso divertimento que termina com a bela Polka das Rosas", seguindo com a comédia em 2 atos O Dr Grama, com Arêas (Dr Grama) e Martinho (Barão Rufino das Dores); a Valsa do balé Gisele, com Clara Ricciolini e Esther Berthani; e a farsa $O$ asno é sempre asno finalizando a noite, com Martinho e Arêas, nos papéis principais. Nos intervalos, valsas e quadrilhas pela orquestra (Diário do Rio de Janeiro, 05 fev. 1855, p.4).
} 
sua separação do grande ator-empresário foi definitiva, pois, em vez de se engajar em outra companhia, como fizera em 1848 e 1851, Velluti organizou um teatro patrocinado pelo negociante e capitalista português Joaquim Heliodoro Gomes dos Santos. Apesar do apagamento que sua atuação nesse projeto obteve na história, sua iniciativa propiciaria condições para a renovação do repertório e também do público do teatro da Corte.

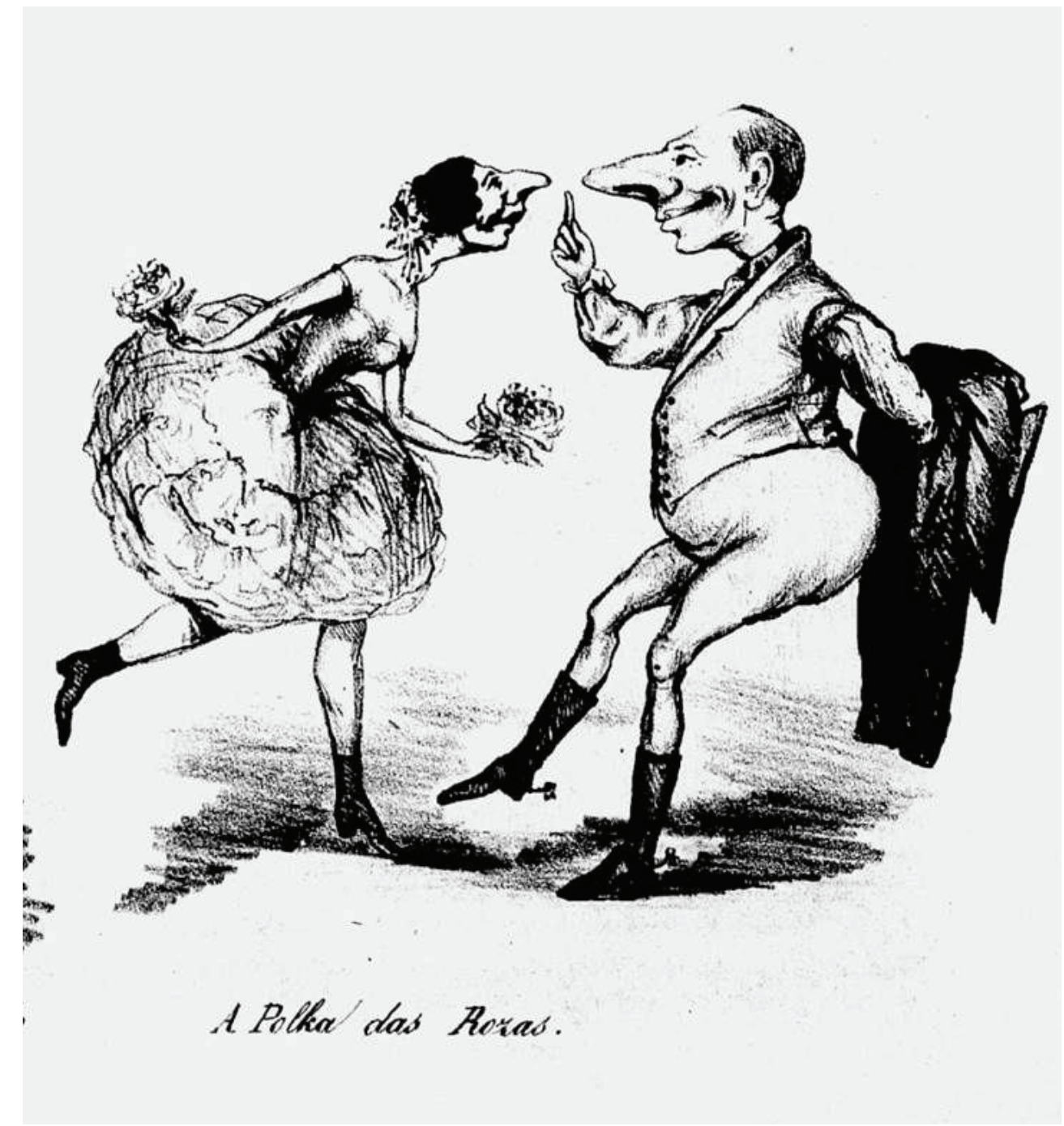

Imagem 3: Uma caricatura de 1855 mostra o ator cômico Martinho Corrêa Vasques em A polka das rosas. Em fevereiro desse ano, Maria Velluti fez com Martinho esse mesmo número de dança que contou também com a participação da bailarina Clara Ricciolini. Fonte: L'Iride Italiana, 28 out. 1855.

\section{Do francês ao nacional}

O Teatro São Francisco foi construído em 1832 pelo francês Victor Chabry para abrigar atores amadores franceses que trabalhavam na rua do Ouvidor. ${ }^{9}$ Possuía 256 lugares, e era considerado um espaço pequeno para apresentação de dramas e comédias. Depois de um período de abandono, foi arrendado e reformado por João Caetano, reabrindo em 02 de maio de 1841, com sua companhia dramática, onde também o

9 O teatro se localizava na antiga rua de São Francisco de Paula, entre os números 27 e 29, fundos para a rua do Cano, número 86 , atual rua Sete de Setembro. A rua de São Francisco de Paula passou a se chamar rua do Theatro ainda no século XIX, nome que mantém até o momento (2019). 
empresário dirigiu uma companhia francesa posteriormente. Depois de mais um período de abandono, o negociante e capitalista Joaquim Heliodoro Gomes dos Santos o alugou para reabri-lo em 1855 com o nome de Teatro Ginásio Dramático.

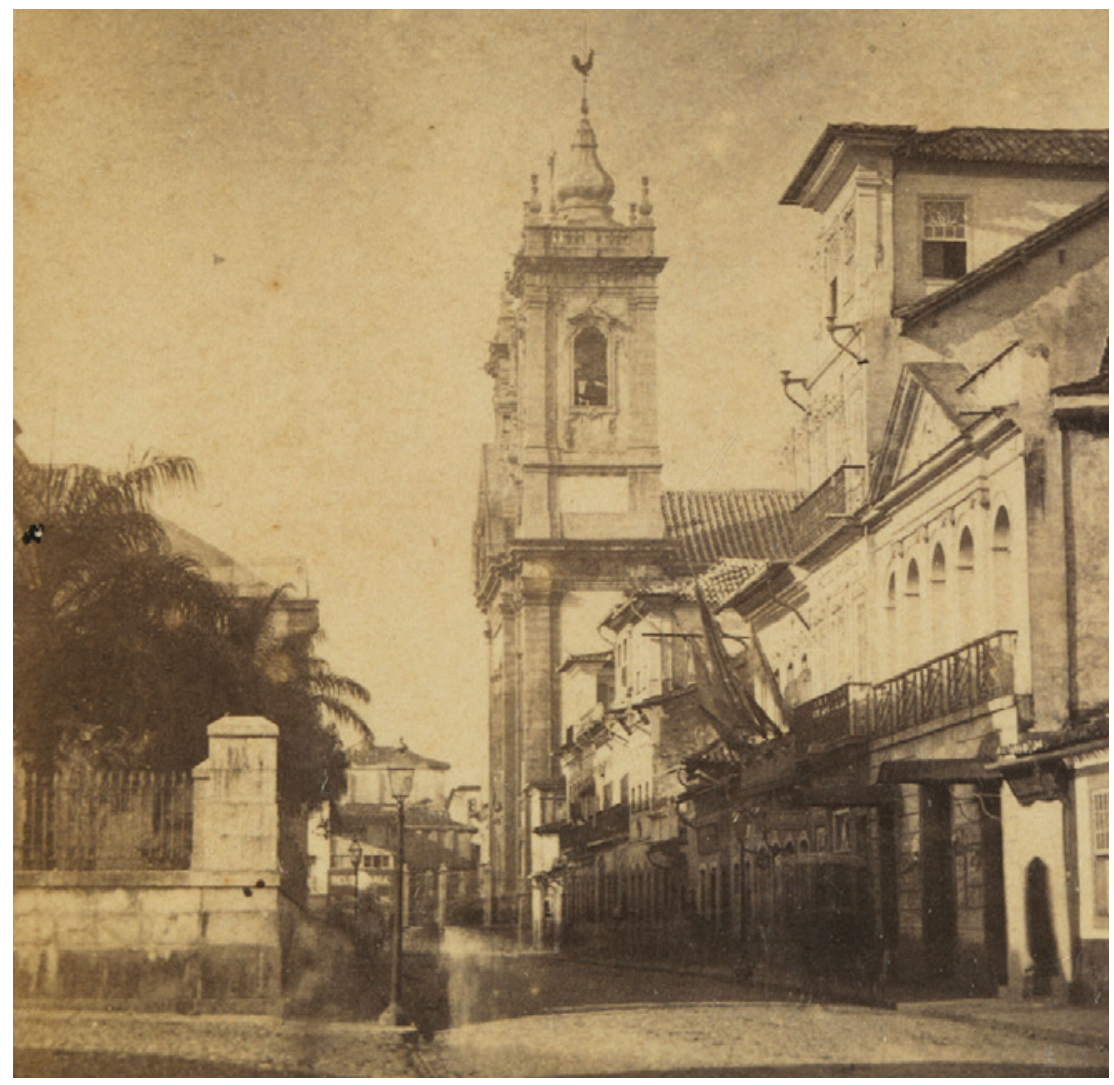

Imagem 4: Fotografia de Klumb mostrando a rua do Theatro, direção largo de São Francisco, com a igreja em último plano. No primeiro plano, vemos o Teatro Ginásio, e pouco depois o Teatro São Luís, com bandeiras na sacada. Esse teatro foi construído por Furtado Coelho e inaugurado em 1870. Velluti ali também se apresentou em 1877. Fonte: "Rua do Theatro", Revert Henrique Klumb (c.1826-c.1886), Oficina de Paulo Robin, s/d. Coleção Thereza Christina Maria. Fundação Biblioteca Nacional do Rio de Janeiro.

Joaquim Heliodoro Gomes dos Santos era português do Porto, filho de Manoel Gomes dos Santos, herói das batalhas no Porto em favor do reinado da irmã de D. Pedro II, Maria da Glória, recebendo por isso as comendas da Ordem de Nossa Senhora da Conceição de Vila Viçosa, que passaria a seu filho Joaquim Heliodoro (Santos, 2016). Ele não era um artista ou empresário de teatro como João Caetano e Florindo Joaquim da Silva. Era um investidor, um negociante, ou seja, um "capitalista". Em 1853, Heliodoro era proprietário de um estabelecimento de "descontos e ordenados, pensões, soldos, terças, montepios, letras" na rua da Alfândega, 95 (Almanak, 1852, p. 487). Há registro de que ele também era o banqueiro que fazia empréstimos para João Caetano a largos juros (Brazil-Theatro, 1903-1904).

A função de acionista de teatro não era inédita para Heliodoro, pois, em abril de 1855, além de inaugurar o Ginásio, o capitalista estava envolvido em um projeto de construção de um teatro para a ópera italiana, e talvez tenha sido um dos que já faziam parte do grupo de acionistas do Teatro Provisório que apresentava esse repertório. Joaquim Heliodoro se comprometia publicamente a ser um dos acionistas de um novo teatro que se chamaria Teatro do Imperador, destinado exclusivamente à encenação de óperas italianas. Fazia ele parte de uma lista extensa de diversos nomes 
importantes que financiariam a construção e o patrocínio desse teatro por oito anos (Jornal do Commercio, 16 abr. 1855, p.2). Não estava Heliodoro alheio ao meio teatral da Corte, no sentido do mecenato, quando investiu na reforma e patrocínio de um teatro já existente, abandonado, pequeno e vizinho ao grande teatro da Corte, o São Pedro de Alcântara, e, por isso mesmo, com chances de enfrentar a conjuntura de uma natural concorrência.

Quando João Caetano despediu Maria Velluti de sua companhia, Heliodoro passou de banqueiro a concorrente do empresário no mundo dos teatros da praça da Constituição. Assim surgiu o Teatro Ginásio Dramático inspirado no Théâtre du Gymnase de Paris, indicando uma intenção didática em seu próprio nome. ${ }^{10}$ No novo teatro se encenariam textos de linha realista, um repertório diferente do romântico encenado por João Caetano no São Pedro.

Heliodoro, Velluti e a nova companhia teatral da Corte não estavam sozinhos. Havia José de Alencar, Machado de Assis, Quintino Bocaiúva, Manuel de Araújo Porto Alegre como divulgadores do Teatro Ginásio na imprensa jovens intelectuais, que além de escreverem em periódicos saudando o novo teatro como uma inovação, tinham projetos de dramaturgia. Como ensaiador, a nova empresa contava com Émile Doux que havia trabalhado como "administrador fiscal" e ensaiador de atores na companhia de João Caetano no São Pedro, um francês radicado no Brasil, mas que viera de Portugal, onde introduzira o vaudeville (Azevedo, 2015; Faria, 1993). Não somente Doux vinha da "escola" de João Caetano, havia outros ex-atores do São Pedro no Ginásio: Joaquim Augusto Ribeiro de Souza, Luís Carlos Amoedo, Luís Cândido Furtado Coelho, Gabriella da Cunha De-Vecchy, Adelaide Amaral, Pedro Joaquim do Amaral e Eugênia Câmara (Faria, 1993).

A nova empresa inaugurou o Ginásio com uma estrutura comum de espetáculo, um drama seguido de comédia: o drama Um Erro, de Eugène Scribe, e a ópera cômica $O$ primo da Califórnia, de Joaquim Manoel de Macedo, com música de Demétrio Rivero, em uma terça-feira, dia 10 de abril de 1855. Velluti participou de ambas as peças, em O primo da Califórnia como "Beatriz, velha criada de Adriano"; em Um Erro, como "Darmantiéres, tia de Leonilda" (Jornal do Commercio, 07 abr. 1855, p.4). ${ }^{11}$ Depois de Scribe, que não era novidade nas imediações da praça da Constituição, estreou no Ginásio a montagem da primeira peça do repertório realista francês, As mulheres de mármore (Les filles de marbre), de Théodore Barrière e Lambert-Thiboust, com tradução de J. J. Vieira Souto, ${ }^{12}$ em 26 de outubro de 1855 (Faria, 1993). Além de Alexandre Dumas Filho -, autor de A dama das camélias, um

\footnotetext{
10 Em 1861, o Teatro Ginásio passou a Joaquim Augusto Ribeiro de Souza e de 1867 a 1868 a Luís Cândido Furtado Coelho (Faria, 1993; Souza, 2002). Em 1878, o teatro foi comprado por Joaquim Antônio Pinheiro, até desaparecer antes da proclamação da República. Entretanto, seu prédio continua na rua do Theatro, vizinho ao mesmo antigo São Pedro, hoje Teatro João Caetano, ao lado do prédio do Instituto de Filosofia e Ciências Sociais da Universidade Federal do Rio de Janeiro. O estado desse prédio histórico para o teatro brasileiro é de verdadeiro abandono e ausência de vestígios sobre a importante história que poderia hoje lembrar.

11 Em O primo da Califórnia o elenco era composto também por Guilherme Orsat (Pantaleão), Luis Carlos Amoedo (Adriano Genipapo), Pedro Joaquim do Amaral (Felisberto), Pedro Montani (Ernesto), Martins (Eduardo), Adelaide Cristina do Amaral (Celestina). Em Um erro, Luís Carlos Amoedo (Conde de Villevalier), Gabriella da Cunha De-Vecchy (Condessa Leonilda), Pedro Joaquim do Amaral (Balthazar), Guilherme Orsat (Graciano Grincheux), Josephina Miró (Josephina) (Jornal do Commercio, 07 abr. 1855, p.4).

12 Monteiro (2016) chama atenção para o nome de José Joaquim Vieira Souto, ator no Ginásio Dramático ao lado de Velluti, que também foi tradutor da companhia, especialmente após 1857, quando suas traduções passaram a ter mais espaço que as de Velluti. Foi Souto o tradutor das versões em português das peças de sucesso da escola realista na França, como As mulheres de mármore e A dama das camélias. Apesar da concorrência, Maria Velluti traduziu 25 peças para 0 Ginásio Dramático na década de 1850, segundo Monteiro.
} 
sucesso do Ginásio - obras de Émile Augier, Théodore Barriére e Octave Feuillet subiram ao palco. A companhia do Ginásio também realizou um repertório do dramalhão francês, ou seja, a autores como Adolphe d'Ennery, Auguste Anicet-Bourgeois, Fernand Dugné e Gustave Lemoine. Nesse momento, Velluti realizou outro papel travesti, depois de ter feito "Um preto" no drama A cisterna arruinada e "um oficial francês" no balé A Cracoviana. Um dos mais lembrados personagens de seu repertório dramático foi o Duque de Richelieu, personagem principal da comédia francesa As primeiras proezas de Richelieu, de Jean-François Bayard e Dumanoir, apresentado no Ginásio em 1855 com grande sucesso em sucessivas representações (Diário do Rio de Janeiro, 28 abr. 1855, p. 2; Muzart, 1999).

Com o português Furtado Coelho como encenador, no lugar de Emile Doux, o Ginásio também montou autores realistas portugueses, - um realismo diferente do francês -, como Mendes Leal Jr, Augusto César de Lacerda, Ernesto Biester e Camilo Castelo Branco entre 1856 a 1860 (Faria, 1993; Souza, 2002).13 Mas o repertório francês ainda era a primazia.

Na abertura do Ginásio, a reunião de um autor francês e um brasileiro indicavam a vocação do novo teatro. Nos primeiros seis meses de atividade, o Ginásio levou ao palco um novo repertório, as comédias francesas, muitas delas traduzidas por Velluti, em um ritmo frenético de produção. Começava assim a carreira de tradutora da atriz e bailarina. Segundo pesquisa de Monteiro (2016), Maria Velluti traduziu, pelo menos, 45 peças ao longo de três décadas de atuação no Brasil, sendo 5 originais do italiano, 37 do francês e 3 originais de idiomas desconhecidos. ${ }^{14}$ No Ginásio, Velluti traduziu oito peças em seu primeiro ano de atuação. ${ }^{15}$ Apesar de tão profícua produção, dizia Velluti que não dava muita importância às suas traduções. No texto dedicado à Ludovina Soares da Costa na introdução do drama $A$ vida de uma atriz, publicado em 1859, ela escreveu:

\footnotetext{
Nunca tive a pretensão de ver alguma das minhas traduções impressas, pois não lhes dava tal importância; e quando me falaram isso, oferecendo-me coadjuvação nesse trabalho, fiquei indecisa e acanhada. Sem tomar uma resolução definitiva, passei em resenha esse repertório por mim traduzido, e deparando-me com o drama em 5 atos, de Bourgois e Barriére - $A$ vida de uma atriz - há bastante assunto para satisfazer o nosso orgulho de classe! (Anicet-Bourgeois; Barriére, 1859, p. 2)
}

Entre 1855 e 1860, a dramaturgia francesa dominava no Ginásio, e somente José de Alencar representou o autor brasileiro quando a sua peça $O$ Rio de Janeiro verso e reverso estreou em 1857, seguida de O demônio familiar, O Crédito e As asas de um anjo, em 1858, todas sob o modelo de Alexandre Dumas Filho, autor que já estava sendo encenado no Ginásio (Faria, 1993).

\footnotetext{
13 Segundo Faria (1993), Scribe não foi substituído pelos dramaturgos realistas. Como o espetáculo era longo, com uma peça principal e outra menor, as comédias curtas e os vaudevilles de Scribe continuaram a ser encenados junto a outros e novos autores no Ginásio como Ancelot, Duport, Clairville, Mareaux, Paul de Kock, Lapointe.

14 Innocencio Francisco da Silva, em seu Dicionario biobibliographico português (1860), dedicou um verbete à Maria Velluti e lista as peças que ela traduziu sem indicar suas fontes de pesquisa (Silva, 1860, p. 438). Bruna Feola Monteiro, em seu texto sobre as traduções de Velluti (2016), indica mais títulos, muitos citados por Silva, e as repercussões dos mesmos. Para conhecimento desses títulos, recomendamos consultar essas fontes.

15 Segundo Monteiro (2016), as peças traduzidas por Velluti no momento inicial do Ginásio foram Luíza ou a reparação, de Scribe; Uma mulher de juízo ou aos 30 anos, de Rosier; As primeiras proezas de Richelieu, de Bayard. Outras obras de autores não identificados, segundo a pesquisadora, foram $A$ atriz, o teatro e os doidos - uma das poucas peças traduzidas por Velluti em que ela não faz parte do elenco -, Os filhos de Adão e Eva; A princesa e a tamanqueira; Dois Augustos e Um francês na Espanha.
} 
Era um teatro moderno para um público "moderno", com base em um repertório importado da França. Essas peças, chamadas também de "peças de tese", traziam temas sobre questões sociais e morais para discussão em cena e atendia a um público burguês que já se formava na França e no Brasil daquele momento. Os autores realistas franceses Alexandre Dumas Filho, Thèodore Barrière, Émile Augier, Octave Feuillet, principalmente, passaram a ser encenados no Ginásio, abrindo caminho para que dramaturgos brasileiros seguissem o mesmo modelo. Esse repertório promoveu uma superação do romantismo teatral representado pelo repertório de João Caetano. Segundo Machado de Assis, era no Ginásio o lugar para um teatro possível onde a "nova escola" ou a "escola moderna" se tornava a saída para o fortalecimento da arte dramática nacional (Machado de Assis, 1873 apud Faria, 2008, p.531-532).

Entre setembro de 1860 a fevereiro de 1862, quando o Ginásio esteve sob a direção de Joaquim Augusto Ribeiro de Souza, uma leva de autores dramáticos brasileiros foi encenada, superando os franceses (Faria, 1993) e fazendo deste o único momento da dramaturgia escrita por brasileiros no século XIX. Finalmente, Machado de Assis e José de Alencar viveram a concretização de suas expectativas sobre o teatro brasileiro por um momento. ${ }^{16}$

Velluti trabalhou intensamente como atriz no repertório de autor nacional brasileiro. Além de O primo da Califórnia na inauguração do Ginásio, Velluti interpretou personagens das primeiras peças de José de Alencar. Em O demônio familiar, fez Henriqueta, uma moça de 18 anos, na estreia que ocorreu em 5 novembro de 1857 (Correio Mercantil, 05 nov. 1857, p.4). ${ }^{17}$

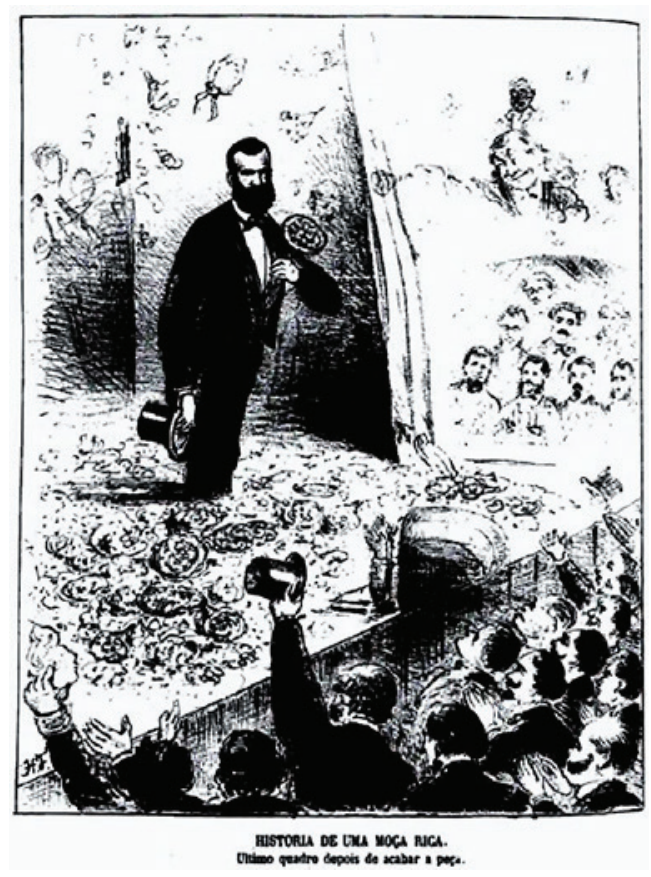

Imagem 5: Francisco Pinheiro Guimarães (1832-1877), um dos autores brasileiros do realismo, retratado no palco do Teatro Ginásio após a apresentação de seu drama História de uma moça rica que estreou em 4 de outubro de 1861, um dos maiores sucessos dessa fase do teatro brasileiro. Fonte: Semana Illustrada, 13 out. 1861.

\footnotetext{
${ }^{16}$ A partir de 1860, diversos textos brasileiros foram encenados no Ginásio, configurando um momento único no século XIX no teatro brasileiro: Luxo e vaidade, $A$ torre em concurso e O novo Otelo, de Joaquim Manoel de Macedo; A Época, de Aquiles Varejão; O Cínico, de Sizenando Barreto Nabuco de Araújo; Sete de Setembro e Amor e dinheiro, de Valentim José da Silveira Lopes; A história de uma moça rica, de Francisco Pinheiro Guimarães; A Resignação, de Aquiles Varejão; De ladrão a Barão, de Francisco Manuel Álvares de Araújo; Os tipos da atualidade, de França Júnior; Um Casamento, de Constantino do Amaral Tavares. E um nome que precisamos destacar, por ser a única mulher do grupo, Maria Angélica Ribeiro, autora de Gabriela e Cancros sociais (Faria, 1993, p.107-111; Guinsburg, 2009, p.293).

17 Além de Velluti, o elenco de estreia de 0 demônio familiar era composto por Pedro Joaquim do Amaral (Dr. Eduardo), Paiva (Azevedo), Almeida (Alfredo), Graça (Vasconcelos), Eulália (Jorge menino), Martins (Pedro crioulo), Adelaide Christina do Amaral (Carlotinha), "Sra" Noronha (D. Maria). A peça foi dedicada à imperatriz Theresa Christina (Correio Mercantil, 05 nov. 1857, p.4).
} 


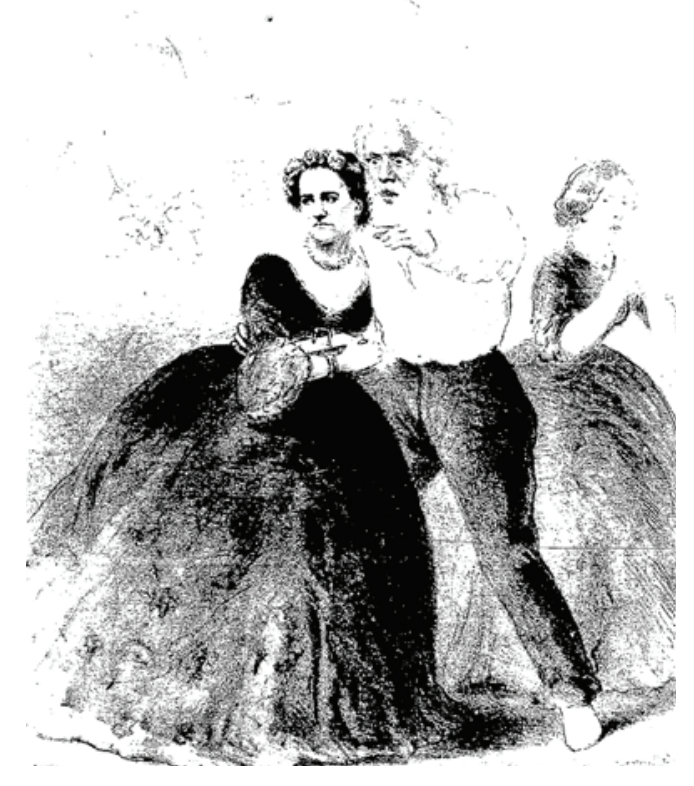

Imagem 6: 0 casal Adelaide Christina da Silva Amaral e Pedro Joaquim da Silva Amaral em cena na peça Lusbela, de Joaquim Manoel de Macedo, encenada no Ginásio em 23 de setembro de 1862. Fonte: Semana llustrada, 05 out. 1862.

De Alencar, Velluti também criou Joana, o primeiro papel do drama Mãe. Importante salientar que essa mãe da peça era uma mulher negra, escrava de seu próprio filho que ignorava ser filho de sua escrava. O drama da personagem se desenvolve sobre o conflito em revelar a maternidade a seu filho branco, pertencente a um círculo social que ela não pertencia. Velluti, depois de fazer "Um preto" no drama A cisterna arruinada, em 1853, agora vivia a protagonista negra de um drama de autor brasileiro. A estreia da peça ocorreu em 15 de março de 1860, como solenidade pelo aniversário da imperatriz, com a presença do casal imperial na sua tribuna $^{18}$ (Jornal do Commercio, 14 mar.1860, p.4).

A protagonista do drama Mãe de Alencar surgiu para Velluti em um momento um pouco conturbado. Dois anos antes, em 1858, a atriz e tradutora havia sofrido ataques dos fãs de Adelaide Amaral, após chegar da Bahia, onde a companhia excursionou, enquanto o Ginásio era reformado. No ano seguinte, ainda teve de enfrentar a concorrência com Eugenia Câmara, portuguesa como ela, que também passava a traduzir peças para a companhia do Ginásio (Monteiro, 2016). A Mãe de Alencar, portanto, representava também uma retomada do seu destaque como atriz.

Machado de Assis, em sua crítica sobre a peça, disse que Maria Velluti deu "relevo ao papel de escrava com essa inteligência e sutileza que completam os artistas" (Diário do Rio de Janeiro, 29 mar. 1860 apud Faria, 2008, p.227). Sobre a Joana de Velluti, lemos ainda em outro folhetim a seguinte avaliação: "a Sra Velluti dando vida abundante e verdadeira ao sentimento da maternidade de que se fazia um tipo sublime" (Diário do Rio de Janeiro, 25 mar. 1860, p. 5). A Joana de Mãe se tornaria, a partir de então, um dos principais papéis de sua carreira. E com ela, Velluti se apresentou em diversas cidades além do palco e do momento importante que o Ginásio representou para o teatro brasileiro.

\footnotetext{
18 O elenco de Mãe era composto por Joaquim Augusto Ribeiro de Souza (Dr. Lima), Paiva (Jorge), Joaquim Heller (Gomes), Militão (Peixoto), Graça (Vicente), Ludovina Soares da Costa (Elisa) e Maria Velluti como Joana, a escrava (Jornal do Commercio, 14 mar. 1860, p.4).
} 


\section{De São Paulo ao nordeste}

Com o drama Mãe de Alencar, Velluti se apresentou em São Paulo dois anos após a estreia da peça no Teatro Ginásio. Ela estava novamente dividindo o palco com o ator Joaquim Augusto Ribeiro de Souza, que interpretou o Dr Lima na estreia. Mas não seria somente no palco a parceria entre o ator brasileiro e a atriz portuguesa. Velluti e Joaquim Augusto se casaram e ela passou a assinar "Maria Velluti Ribeiro de Souza"19 (Correio Paulistano, 06 nov. 1868, p.4).

A presença de Velluti em São Paulo, onde a programação teatral não era muito regular, trouxe alguma esperança, pois "falava-se" que ela organizaria uma companhia no Teatro São José. Assim lemos em um texto publicado na ocasião da apresentação de Mãe em um benefício de agosto de 1862:

Domingo faz beneficio a atriz Velluti. Leva a cena o belo drama do Sr Alencar Mãe. Fala-se por aqui que essa distinta atriz tomará conta da empresa do nosso teatro. Cremos que, se o fizer, não se arrependerá. O público de S. Paulo sabe aquilatar os talentos da Sra Velluti, e, pois, confiando que sob sua direção o teatro se emancipará, lhe há de prestar valioso apoio. Pensam erradamente os que dizem que S. Paulo não pode ter uma companhia de teatro permanente. O que S. Paulo não pode ainda é sustentar atores e atrizes de $500 \$$ e $600 \$$ por mês; estes devem simplesmente vir de vez em quando, mas nunca ficar. Uma companhia composta de dez a doze atores, duas ou três damas, todos de mediana força, dirigida e ensaiada por pessoa inteligente e que saiba escolher peças de força dos artistas, eis o que S. Paulo precisa e quer, e a Sra Velluti é por demais apta a realizar este desideratum. (Diário do Rio de Janeiro, 20 ago. 1862, p.2).

Velluti já estava em São Paulo alguns meses antes desse benefício. Sua estreia no Teatro São José ocorrera em 03 de maio de 1862 com a "comédia-drama" Um segredo, no espetáculo "em aplauso a abertura da Assembleia Legislativa". Nesse elenco, estavam também o primeiro-ator Joaquim Augusto, seu filho Joaquim (Augusto) Júnior, Vasques, Madalena, Miguel, Gonçalves e Peregrino (Correio Paulistano, 02 maio 1862, p.4). Velluti também realizava papéis nas comédias curtas em finais de dramas. Em 12 de outubro de 1862, por exemplo, ela esteve na comédia Maricota ou os efeitos da educação, de Severiano Cardoso, que sucedeu uma outra apresentação do drama Mãe, onde a atriz foi chamada à cena três vezes para receber uma "grande ovação" do público (Correio Paulistano, 14 ou. 1862, p.1).

De fato, uma empresa foi organizada com Velluti para o Teatro São José, mas com o nome do seu marido em destaque, o primeiro-ator Joaquim Augusto Ribeiro de Souza, que se juntou ao empresário e criador do teatro, Antônio Bernardo Quartim, para criar uma nova companhia dramática ${ }^{20}$ com uma subvenção do governo local no valor de 4.000 réis (Silva, 2008). A estreia ocorreu em 29 de novembro de

\footnotetext{
19 Não sabemos precisar a data exata do casamento de Joaquim Augusto e Maria Velluti. Por base nas pesquisas em periódicos, supomos que tenha sido no começo da década de 1860. Para determinar essa data teríamos que pesquisar seu registro de matrimônio em arquivos eclesiásticos, o que ainda não foi possível realizar. Certamente eram casados oficialmente, pois Velluti era solteira, e encontramos um comunicado de 1893 da "Recebedoria da Capital Federal" sobre imposto predial, onde consta o sobrenome "Ribeiro de Souza" em seu nome (O Tempo, 24 ago. 1893, p. 2).

${ }^{20}$ Além de Velluti, a companhia era composta pelas atrizes Júlia Carlota de Oliveira, Benedita Maria Santos, Minervina Rosa Gonçalves, Filadefa Louro, e pelos atores Joaquim Augusto Filho (filho de Joaquim Augusto), Henrique Costa, João Elói Quevedo, José Vitorino da Silva Azevedo, Francisco de Assis Gonçalves, Francisco Correia Vasques, Paulo Eduardo Petit, Augusto Montani e Luís Paulino além do próprio Joaquim Augusto que também era ator da nova companhia (Silva, 2008, p. 39).
} 
1862 com Luxo e vaidade, de Joaquim Manoel de Macedo, e um elenco composto por Joaquim Augusto, Maria Velluti, Júlia Azevedo, José Victorino, João Eloy, Joaquim Augusto Filho. ${ }^{21} \mathrm{O}$ folhetim teatral do Correio Paulistano assim noticiou sobre a nova companhia do São José:

O seu repertório pela maior parte nacional em pouco tempo por-nos-á o fato e far-nos-á conhecer todas as peças dramáticas ultimamente representadas na Corte e recebidas brilhantemente pela inteligente plateia do Ginásio e pela sua ilustrada imprensa seja política ou literária (Correio Paulistano, 28 nov. 1862, p. 1$)$.

A nova empresa do Teatro São José trazia para São Paulo textos dos autores brasileiros, portugueses e franceses encenados no Ginásio. Em 1863, por exemplo, a Companhia Joaquim Augusto levou à cena a comédia $A$ batalha das damas ou um duelo em amor, traduzida do francês por Velluti (Correio Paulistano, 05 fev. 1863, p.4). Em plena guerra do Paraguai (1864-1870), o poema patriótico também surgiu no repertório da atriz em São Paulo. Em espetáculo de benefício em $1865,{ }^{22}$ depois da apresentação das comédias Rabecão e Os amores de Cleópatra, Velluti recitou a poesia Voluntários da morte. Sobre a apresentação assim registrou o Correio Paulistano:

A distinta beneficiada revelou-se grande artista! Ali brilhou com esplendor toda força do seu talento. Inspirada, ela interpretou fielmente no gosto, na eloquência do sentimento, na finura do estilo elevado de uma perfeita escola dramática os grandes pensamentos do ilustre poeta. O artista que com a Sra Velluti traduz as criações do gênio pode colocar-se sem receio a par dos artistas de primeira ordem. A Sra Velluti é simpática em extremo, graciosa na comédia, inspirada na criação dos grandes pensamentos e majestosa como rainha em personagens da alta aristocracia. O público vê sempre com prazer a ilustre atriz (Correio Paulistano, 17 set. 1865, p.4).

\footnotetext{
21 O ator Augusto Filho -, também chamado de "Joaquim Augusto Filho", "Augusto Fo", "Augusto Jr" ou "Joaquim Jr"-, aparece como filho do grande ator "Joaquim Augusto" nas crônicas teatrais de São Paulo. Ele esteve em elencos junto a Maria Velluti e a seu pai na companhia dramática, empresariada por Quartim, no Teatro São José. Entretanto, não possuímos fontes que confirmem ser ele um filho do ator com Maria Velluti, ou o filho de Maria Velluti com Almeida Garrett, o que cremos ser hipótese improvável. Nas crônicas e notícias teatrais da época não encontramos nenhuma relação do ator Augusto Filho com Maria Velluti, apesar de estarem, por muitas vezes, nos mesmos elencos.

22 O espetáculo de benefício era um direito dos artistas determinado em contrato com o teatro. A renda da noite era revertida ao beneficiado, descontadas as partes previamente contratadas pelo aluguel do teatro e equipe técnica ou pelo pagamento a uma companhia, que poderia vender um de seus espetáculos para benefício de outros artistas.
} 


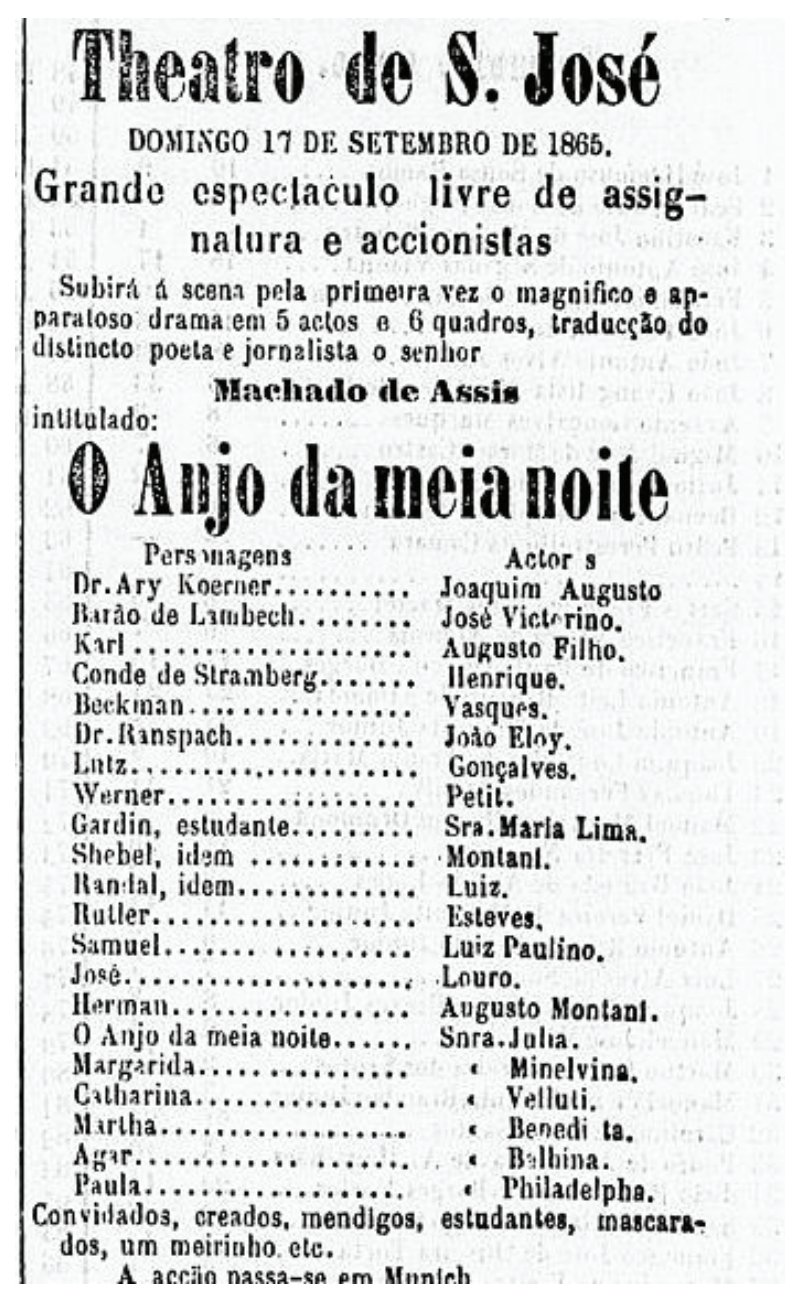

Imagem 7: Anúncio com Maria Velluti no elenco de 0 anjo da meia noite, de Théodore Barrière e Edouard Plouvier, com tradução de Machado de Assis, no Teatro São José, São Paulo, em 1865. Fonte: Correio Paulistano, 17 set. 1865.

A companhia também apresentou, em 1866, dramas como As mulheres de mármore, de Theódore Barriére e Lambert Thiboust, tradução de José Joaquim Vieira Souto; Os homens de mármore, de Mendes Leal, e Suplício de mulher, de Émile de Gerardin e Alexandre Dumas Filho, com tradução de Machado de Assis (Silva, 2008, p.40). ${ }^{23}$ Entretanto, nesse ano de 1866, Joaquim Augusto saiu da companhia, o que levou à perda da subvenção governamental e a consequente dissolução da empresa, apesar das tentativas do empresário Quartim para reverter a decisão do governo. ${ }^{24}$ No São José, Velluti fez, em 1865, a Marquesa d Álvedra de As joias da família, comédia drama de Augusto Cezar de Lacerda; a Bernarda em Feio de corpo, bonito de alma, comédia drama de José Romano; e D. Guilherma de Mello em A Probidade, drama de Cézar de Lacerda (Silva, 2008, p. 261-263).

De São Paulo o casal seguiu para o nordeste, contratado por empresários teatrais locais. Em 1867, Vicente Pontes de Oliveira trouxe Velluti e Joaquim Augusto

\footnotetext{
23 Pires de Almeida informa que Velluti lhe encomendara uma peça para seu benefício. A obra intitulada O Mulato apresentava temática abolicionista e foi encenada em São Paulo. Não encontramos referência desse espetáculo, mas vale o registro da informação para que se desenhe um perfil da atriz (Brazil-Theatro, 1903-1904, p.253).

24 Quartim enviou ofício ao governo para a manutenção do financiamento estatal revelando a situação de penúria em que ficariam as famílias dos atores e o fim da única diversão na província. O governo manteve sua decisão argumentando que sem o ator Joaquim Augusto eram inviáveis as condições artísticas da companhia dramática. Após a dissolução da companhia de Quartim, o prestidigitador e empresário J. B. Linsky ocupou o Teatro São José até 1868 (Silva, 2008, p. 40-41).
} 
para a companhia do Teatro São Luiz, em São Luiz, Maranhão, com o ator assumindo também o cargo de diretor artístico da companhia.

Após a temporada ludovicense, Joaquim Augusto e Maria Velluti foram contratados por José Duarte Coimbra, empresário do Teatro Santa Isabel, no Recife, Pernambuco, no início de 1868. Além de ator, Joaquim Augusto, mais uma vez, assumiu a função de "diretor de cena". A estreia ocorreu em 5 de fevereiro daquele ano, com o espetáculo $O$ Pelotiqueiro, de Paulin Menier, mesmo drama apresentado na temporada de São Luiz. $^{25}$ Joaquim Augusto e Velluti foram assim apresentados ao público recifense:

[...] talento apreciado com gosto em Lisboa e no Porto, é o Sr Joaquim Augusto uma das glórias do teatro brasileiro, notabilidade assaz aplaudida no império, com especialidade no Rio de Janeiro, S. Paulo, Bahia, Maranhão e Pará, onde conseguiu obter a simpatia que só se tem aos gênios artísticos, e que pela primeira vez veio trabalhar em nosso teatro, com a sua mulher, a Exma. Sra. D. Maria Velluti Ribeiro de Souza, centro nobre, cujo poder cênico corresponde ao grande conceito, que n'arte se lhe tributa pela corrente magnética, com que prende o espectador à personagem dramática, fazendo sobressair as belezas que criou a imaginação do dramaturgo. (Jornal do Recife, 01 fev. 1868, p.3)

Seis dramas compunham o novo repertório do Santa Isabel pela companhia protagonizada pelo casal de atores. ${ }^{26}$ Soma-se a esse repertório o drama de Gonçalves de Magalhães, Antonio José ou o poeta e a inquisição, com Joaquim Augusto como Antônio José, e Maria Velluti como Marianna, personagens criados por outro casal, João Caetano e Estella Sezefreda, na estreia histórica de $1838^{27}$ (Jornal do Recife, 05 maio 1868, p.3).

O casal voltou para a Corte e se engajou na companhia do ator Martins no Teatro São Pedro de Alcântara com Joaquim Augusto como diretor de cena, mas, em 1869, eles estavam de volta ao Recife (Correio Mercantil, 05 set. 1868, p.2; $A$ Vida Fluminense, 12/09/1868). Nessa volta, ainda na empresa dramática de Duarte Coimbra no Teatro Santa Isabel, Velluti levou à cena uma peça inédita de sua autoria intitulada Mulher que perde e mulher que salva em 20 de maio de 1869, anunciado como um "drama em 1 ato, original brasileiro, composto pela atriz do Teatro Santa Isabel", e oferecido "às senhoras de Pernambuco". Velluti interpretava o primeiro papel feminino de seu texto, a cega D. Leopoldina, esposa do Dr. Álvaro Cunha, interpretado por Joaquim Augusto. No elenco, havia ainda J. Thomaz Espiunca (Brigadeiro Galvão), a menina Zulmira (Bazília, filha de Leopoldina), Joaquim Antônio Brochado (Custódio, criado velho), Júlia Carlota de Aze-

\footnotetext{
25 No primeiro espetáculo, o elenco foi composto pelos atores, Thomaz Espiunca, Barreto, Gomes, Joaquim Augusto, Pedro, Antônio José Peixoto, Guimarães, Barreto, Flaviano, Alexandrino, Gil e as atrizes Maria Velluti, Camilla Guimarães, Jesuína, Júlia Carlota de Azevedo, Bernardina. (Jornal do Recife, 01 fev. 1868, p.3).

26 A companhia incluía outro casal, o ator Joaquim Antonio Brochado e a atriz Carolina Augusta Brochado que chegaram do Sul. 0 ator Thomaz Espiunca, que já estava no Santa Isabel, foi incluído na nova companhia. Uma assinatura foi aberta oferecendo 36 apresentações em 3 séries com as peças: 0 Pelotiqueiro (Paulin Mennier, tradução de Oliveira de Araújo), O louco por amor, Frei Luiz, Trothman, Cabo Simão, Christovão Colombo. Posteriormente, Eduardo Álvares da Silva e Martinho Corrêa Vasques integraram a companhia, estreando juntos em 24 de fevereiro de 1869, no drama de Anicet Borgeois, Christol, o enforcado, com Martinho fazendo Christol, e Eduardo como Gilberto D’Artigues, em um elenco composto por Velluti, Julia Carlota de Azevedo, Apolônia Jordani, Clélia (de Araújo), Joaquim Augusto, Primo da Costa, Jordani, Santa Roza, J. Victorino, J. Guimarães e Glaviano (Jornal do Recife, 01 fev. 1868, p.3).

${ }_{27} \mathrm{O}$ drama de Magalhães é considerado o primeiro drama de autor brasileiro a ser encenado no país. No Recife, a peça foi apresentada em récita extra, no benefício de Maria Velluti em 5 de maio de 1868 no Teatro Santa Isabel. No elenco, Brochado (Frei Gil), C. Rocha (Conde de Ericeira), Clelia (Lucia), Gomes (Um criado). A comédia em um ato A Moleira de Marly, com Velluti, Camilla Guimarães, Gomes, Graça e Carolina Brochado, foi apresentada em seguida. E a canção A Tonalha Espanhola, pelo casal Munhoz e o ator Brochado, encerrou o espetáculo (Jornal do Recife, 05 maio 1868, p.3).
} 
vedo (Mme Delennag, viúva moça) e Jordani (Gabriel, moleque) (Jornal do Recife, 20/05/1869, p.3). Em junho do mesmo ano, um espetáculo em benefício de Velluti levou o drama ao palco novamente, com o mesmo elenco, exceto o papel do Brigadeiro Galvão que foi interpretado pelo ator J. Victorino. ${ }^{28} \mathrm{~A}$ ação se passava em uma "casa às margens do Capibaribe, época atual" (Jornal do Recife, 09 jun. 1869, p.3). Tanto a dedicatória às senhoras pernambucanas como o local da ação eram formas de promover uma aceitação a sua estreia como dramaturga. Velluti também utilizou seu próprio prestígio como atriz, pois interpretava a protagonista de seu texto. ${ }^{29}$

$\mathrm{Na}$ Corte, apesar de um concorrido mercado teatral, Velluti também conseguiu levar ao palco sua peça, quatro anos depois da sua estreia no Recife. Os cariocas assistiram ao "drama original brasileiro", Mulher que perde e mulher que salva, escrito por uma atriz portuguesa radicada no país, no Teatro Ginásio em 01 de novembro de 1873, em espetáculo de benefício da atriz-autora. A sua peça conseguiu realizar três representações seguidamente ( $A$ Nação, 01 nov. 1873, p.3).

Importante destacar que, no momento da encenação da peça de Velluti, havia uma ausência de textos nacionais sendo realizados na Corte. A programação teatral era basicamente composta por espetáculos de mágica, encenações grandiosas, e o drama Mulher que perde e mulher que salva parecia ser o oposto disto. As mágicas dominavam a programação e o gosto do público. Eram esses os espetáculos com textos em segundo plano, em traduções ou adaptações, onde a encenação era potente em detrimento do texto, e que se realizava mais centradamente na música, na dança, na grandiosidade de cenários, nos figurinos e truques dos maquinismos. Nesse sentido, quando Velluti conseguiu romper esse modelo e achar um lugar nesse mercado para sua peça, significaria o prestígio e o poder de realização que a artista ainda exercia. Um comentarista no periódico 0 Mosquito (01 nov. 1873, p.7) situa a apresentação da peça sob a perspectiva da ausência de textos nacionais. Interessante observar aqui o cronista que considera a peça uma "produção nacional", apesar da nacionalidade portuguesa da autora:

[...] o que eu quero apenas sublinhar é que a Sra Velluti leva a cena um drama seu, Mulher que perde e mulher que salva. É, na verdade, para os nossos dramaturgos que uma mulher quem thes dê o exemplo do trabalho, afoutando-se a levar à cena uma produção nacional. Ou todos os nossos escritores dramáticos repentinamente caíram em esterilidade ou, então, não sei.

\footnotetext{
${ }^{28}$ A peça de Velluti foi apresentada pela segunda vez em um espetáculo de seu beneficio que incluiu outras atrações: Apolônia Jordani apresentou a cena Vinte e seis noivos perdidos; Julia, Joaquim Augusto, Couto e Eduardo fizeram a "fantasia trágica do distinto poeta pernambucano, o Sr. Victoriano Palhares, Romeu e Julieta". Houve também a primeira representação da comédia em um ato traduzida do francês por Velluti, Um marido nas palminhas, com Velluti no papel de Cesarina e Martinho Corrêa Vasques como Hyppolito. Finalizando, a comédia em dois atos, com música do maestro português Francisco de Sá Noronha, Os efeitos de um eclipse, com Couto Rocha, Jordani, Martinho, Clelia e Apolonia (Jornal do Recife, 09 jun. 1869, p.3). Infelizmente, até o momento (fevereiro de 2019), não localizamos o texto Mulher que perde e mulher que salva, de Maria Velluti. As críticas e comentários na imprensa fornecem os nomes dos personagens, mas nenhuma informação sobre o enredo da peça.

29 Após a temporada no Recife, Joaquim Augusto e Maria Velluti fizeram parte da Companhia Cabral em sua última fase, na cidade de Pelotas, em 1870. A companhia era composta pelos filhos do empresário José de Almeida Cabral, Cabral Jr e Maria Augusta - filha de Cabral e Augusta Candiani - e demais atores conhecidos na Corte, tais como Maria Lima, Antonina Marquelou, Barbosa e Motta (O Commercial, 15 out. 1870, p.1). Sobre esse trabalho, não conseguimos referências relevantes.
} 
Após a estreia, o mesmo escritor volta ao tema no periódico revelando a "enchente", ou seja, a maciça presença do público no benefício de Velluti:

O benefício da Sra Velluti foi uma enchente no Ginásio, e uma prova de que não faltam animação aos artistas que procuram bem merecê-la. Isto faz-me crer que a decadência da arte dramática é mais depressa imputável aos artistas, que se julgam dispensados de estudar, e aos empresários, que são ou simples negociantes de espetáculos ou perfeitas nulidades sem ilustração e bom senso, do que mesmo ao público [...]. (O Mosquito, 08 nov. 1873, p.7)

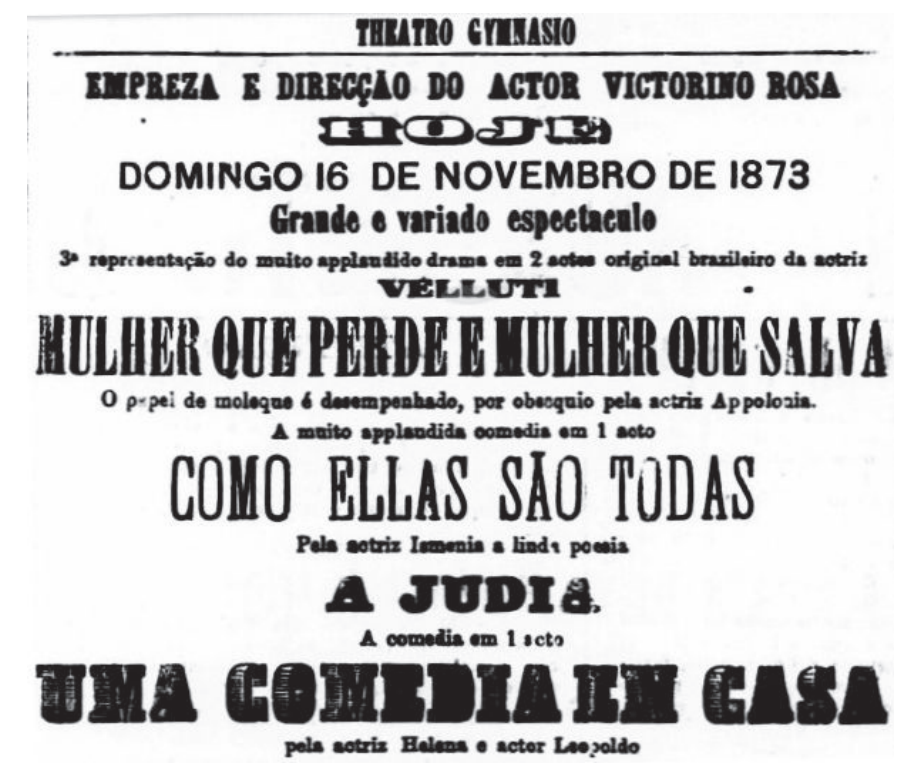

Imagem 8: Estreia da peça de Maria Velluti, Mulher que perde e mulher que salva, no Teatro Ginásio em 1873. Fonte: Jornal do Commercio, 16 nov. 1873.

Apesar do reconhecimento, Velluti foi buscar outras praças com seu drama. Em abril de 1874, ela foi contratada para se apresentar na Bahia. Na ocasião, foi emitido um parecer de recomendação para aferir a reputação dos artistas da companhia, pedido pela província baiana. A própria Velluti assim escreveu no Jornal do Commercio (19 ago. 1874, p.1) sobre sua reputação artística reproduzindo o parecer da comissão baiana sobre sua peça:

Correm diversas versões que podem afetar a reputação dos artistas dramáticos que em abril do corrente ano foram escriturados para a Bahia: por minha parte procurarei isentar-me de qualquer delas, publicando o parecer que a meu respeito enunciou a "comissão julgadora" nomeada pelo governo daquela província a fim de proferir sobre a competência da companhia: $\mathrm{O}$ artista que precisa viver de seu crédito é obrigado a certos e necessários esclarecimentos, embora muito repugnem a sua modéstia. Diz o parecer da comissão: "A atriz Sra Velluti, mestra na arte, e nela bastante instruída, e que tem trabalhado em diversos teatros, só por esta parte revelaria merecimento, se, aliás, em papéis especiais ou especialíssimos não houvesse conquistado merecidos aplausos. No drama Mulher que perde e mulher que salva composição da mesma atriz, verifica-se o nosso conceito. De fato, nesse drama, cuja recomendação cifra-se na unção poética e sentimental que lhe imprimiu sua autora, criando para si uma personalidade, que é a reprodução, talvez ao vivo, da sua própria natureza e constituição sobressaiu a maestria da artista, realçada pelos retoques do talento criador: dir-se-ia um coração dorido que se expunha em espetáculo à simpatia do Infortúnio: eram vozes d'alma, moduladas no diapasão da desgraça. O seu desempenho honrou-a". Um tal parecer de uma comissão julgadora (aliás bem difícil de contentar...) não desloca a artista do seu primeiro lugar na arte dramática. M. V. R. S. Rio de Janeiro. 
Nesse momento, Velluti era uma mulher viúva. Seu marido, o ator Joaquim Augusto faleceu no dia 17 de janeiro de 1873, aos 45 anos, na casa onde o casal residia no bairro de Todos os Santos, (atual região do Méier, zona norte da cidade do Rio de Janeiro), à rua da Boa Vista, número $01^{30}$ (O Paiz, 25 ago. 1893, p.3).

Mesmo após a viuvez, e com idade avançada para uma mulher no século XIX, Velluti não se afastou dos palcos. As décadas de 1870 e 1880 foram bastante produtivas. Encontramos Velluti em diversos teatros dentro e fora da Corte. Na Corte, ela estreou no Teatro São Luiz em A doida de Montmayor, na empresa dramática da atriz Ismênia, em $1874^{31}$ (Jornal do Commercio, 31 dez. 1874, p.6).

Por dois anos, 1877 e 1878, Velluti esteve em Campos dos Goytacazes, atualmente cidade do estado do Rio de Janeiro. A atriz se apresentou no Teatro São Salvador, contratada pela associação empresária dirigida pelo ator Primo da Costa, em 1877, e pelo ator José de Azurara, em 1878, ambos colegas de tempos recifenses. No repertório, Velluti ainda encenava as peças Mãe e Demônio Familiar, de José de Alencar, além de outros títulos apresentados no Ginásio em sua época mais produtiva, como Estátua de carne e O anjo da meia-noite entre outros. ${ }^{32}$ (Monitor Campista, 31/10/1877, p.3).

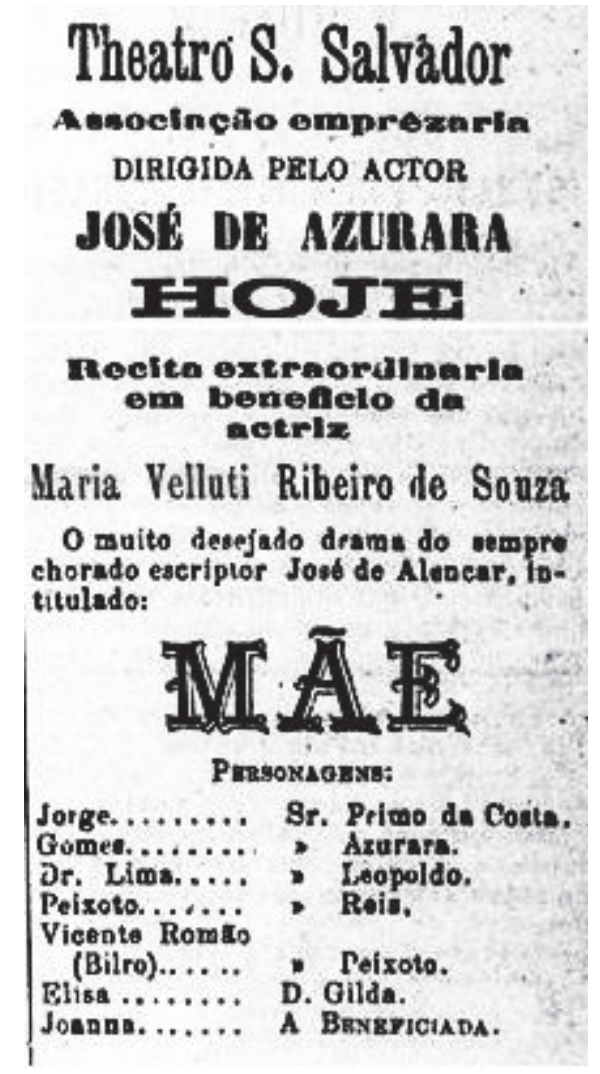

Imagem 9: Anúncio do drama Mãe de José de Alencar no Teatro São Salvador, Campos do Goytacazes, em 1878, com Velluti no elenco.

Fonte: Monitor Campista, 07-08, jan. 1878.

\footnotetext{
${ }^{30} \mathrm{O}$ ator nasceu no Rio de Janeiro em 06 de julho de 1825. Em 1841, aos 16 anos, iniciou sua carreira na companhia de João Caetano, mas foi despedido pelo empresário, provavelmente por apresentar uma certa gagueira e um problema de audição. Trabalhou como contrarregra na mesma companhia e retomou a carreira de ator posteriormente. Atuou em diversas cidades no Brasil e em Lisboa. Em uma temporada paulista conheceu o poeta Castro Alves que lhe dedicou a poesia Ao ator Joaquim Augusto em Espumas Flutuantes (1870). Segundo Sousa Bastos, Joaquim Augusto foi o ator mais querido do Brasil depois de João Caetano (Sousa Bastos, 1898, p. 43, 250, 251).

31 Velluti fazia o papel de Úrsula, com a atriz-empresária no papel da protagonista da peça e com Dias Braga e Primo da Costa no elenco.

32 A companhia era composta pelas atrizes Velluti, Edelvira, Gilda, Eufrásia, Cecilia; e os atores Primo da Costa, Barbosa, Azurara, Leopoldo, Soares, Porto, Guerreiro, Fernando Lima e João Fonseca.
} 
O drama Mãe era uma peça sempre presente em seus benefícios, o que pode indicar uma importância e preferência de seu público por esse papel, tendo em vista o critério de escolha das peças representativas de um artista, quando realizavam esse modelo de espetáculo.

Outra importante obra de seu repertório foi a cena dramática Clara Camarão e O Gênio do Brasil, uma obra em versos de autoria do poeta rio-grandense Bernardo Taveira Júnior. Apresentada após Mãe, no Teatro São Salvador, em Campos dos Goytacazes, em 6 de janeiro de 1878, havia notícias da apresentação da cena nas passagens da atriz pela Bahia, Pernambuco e Rio Grande do Sul (Monitor Campista, 05 jan. 1878).

Composta por dois personagens, Clara e o Gênio (na apresentação de Campos, interpretado por Gilda), a cena parece um resquício dos espetáculos que foram criados, especialmente os dessa modalidade de cenas curtas, na ocasião da Guerra do Paraguai no sul. A cena trazia o episódio histórico da época da dominação holandesa no estado de Pernambuco, e sua "apoteose" era a apresentação do Hino Nacional brasileiro. O tema era nacionalista, onde uma atriz portuguesa interpretava uma heroína que livrava o Brasil do jugo estrangeiro. Os anúncios da "cena" assim resumem a obra:

Clara, esposa do general indígena Felipe Camarão, aliado dos brasileiros, mulher corajosa e guerreira, vai a frente das fileiras combater o holandês. Clara pratica atos de heroísmo; vence, e o Brasil liberta-se do predomínio estrangeiro. O poeta imagina o gênio protetor do Brasil descendo a terra a fim de inspirar sentimentos patrióticos em Clara que outra Joanna D'Arc vai combater pelo Brasil, como aquela outrora foi combater pela França (Monitor Campista, 05 jan. 1878, p.3).

De volta à Corte, Velluti foi atriz de mágicas, pois esse era o gênero de espetáculo mais exibido a partir da década de 1870. Contratada pela empresa do ator J. A. do Valle, a atriz trabalhou no Teatro São Luiz ${ }^{33}$ (Diário do Rio de Janeiro, 25 jan. 1877, p.4), no Teatro Fênix Dramática e na empresa dramática do ator Torres ${ }^{34}$ (Gazeta da Tarde, 22 jul. 1882, p.4). Também fez parte do elenco de Emília Adelaide, diretora da Companhia Dramática Portuguesa, no Teatro-Circo ${ }^{35}$ (Jornal do Commercio, 29 nov. 1879, p.6). No Teatro São Pedro de Alcântara, retornou à cena na companhia de Guilherme da Silveira, com Martinho Corrêa Vasques e Guilherme de Aguiar como colegas de elenco ${ }^{36}(O$ Globo, 28 maio 1875, p.3).

\footnotetext{
${ }^{33}$ A $16^{a}$ récita da companhia apresentou a segunda representação do drama em 5 atos e 8 quadros, com tradução de Eduardo Garrido, As duas órfãs, no qual Velluti integrava o elenco.

34 No Teatro Fênix Dramática, empresa dramática sob direção do ator Torres, "reabertura do elegante teatro" com a estreia de Paulo e Virginia, drama em 4 atos e 5 quadros, adaptado da "bem conhecida novela de B. de Saint Pierre", com Apolonia, Torres, Amoedo, Muniz, Pereira, Phebo, Monclar, Bastos, Nogueira, Vicente, Velluti, Dolores, Phebo e Gertrudes Monclar.

35 Emília Adelaide era diretora da Companhia Dramática Portuguesa no Teatro São Luiz, e se transferiu para o Theatro-Circo, dirigido por Perrini e localizado na rua do Lavradio 94, quando o São Luiz fechou para reformas. A récita de estreia no novo espaço em 30 de novembro de 1879 foi anunciada com presença dos imperadores e com a "reaparição da talentosa atriz Maria Velluti que desempenhará o difícil papel da pobre La Frochard" no drama em 5 atos e 8 quadros de d’Ennery, As duas órfãs.

36 Também Leolinda, Adelaide, Fraga e Silva Pereira formando elenco do espetáculo Noites da Índia, com "aparatosos cenários e adornado de música", na reabertura do São Pedro após reformas.
} 


\section{Um monumento}

Em 1881, em um beneficio do ator e empresário Guilherme de Aguiar, no Teatro Recreio, Velluti reapareceu como atriz depois de alguns anos afastada dos palcos. Sobre esse retorno, assim escreveram na Revista llustrada (nov. 1881, p.7):

A Sra Velluti, a nossa Candiani do teatro dramático, é já um monumento. Os que a viram representar falam vagamente disso como um dilúvio. [...] A Sra Velluti não é, porém, um monumento empoeirado. Durante seu longo eclipse do teatro, acompanhou sempre o movimento artístico, lendo, criticando e até traduzindo peças. ${ }^{37}$

Apesar de não ser um "monumento empoeirado" em 1881, Maria Velluti estava muitos anos longe do teatro quando faleceu no Rio de Janeiro no dia 15 de julho de 1891. Passara seus últimos dez anos praticamente fora dos palcos, mas trabalhando como professora de inglês em sua residência. Seus últimos dias talvez tenham sido na mesma casa da rua da Boa Vista, número 01, onde morou com seu marido Joaquim Augusto no subúrbio de Todos os Santos. ${ }^{38}$ Entretanto, há também uma informação de que ela esteve temporariamente vivendo em Icaraí, Niterói $(R J)$, nesses últimos momentos de vida, onde fazia "longos passeios, cercada das discípulas que a respeitavam e amavam" - assim testemunhou Corina Coaracy em uma crônica sobre Velluti (Muzart,1999). Além das aulas de inglês, Velluti contava com uma pensão fornecida pela Condessa Daupias, ${ }^{39}$ de Lisboa, que o comerciante Antônio da Silva Ferreira, estabelecido no Rio de Janeiro, intermediava a entrega à atriz (O Tempo, 18 jul. 1891, p.2). A única notícia mais séria que encontramos sobre seu falecimento foi um obituário publicado na página de capa do jornal $O$ Tempo (17 jul. 1891, p.1) informando também que ela estava esquecida de todos, até mesmo da imprensa. No texto do obituário, um autor anônimo relembrava os "áureos tempos" do teatro brasileiro, e Velluti como escritora, tradutora e atriz:

Quem se recorda do teatro brasileiro dos seus áureos tempos de Pinheiro Guimarães, Macedo, Alencar, Machado de Assis e outros devem lembrar-se de Maria Velluti que, se não era uma atriz de nomeada, era uma escritora emérita e, como tradutora, ainda melhores traduções não foram feitas da "Viúva das Camélias" e outras peças teatrais e romances como "Jacopo Ortis" e outros. Nos jornais e revistas literárias de Portugal e Brasil o nome de Maria Velluti fulgou ou por muito tempo com brilho invejado por literatos de um e do outro sexo.

\footnotetext{
37 Aqui a comparação é com a cantora lírica e também atriz Augusta Candiani (1820-1890) que encenou a primeira Norma na ópera homônima de Vincenzo Bellini, no Rio de Janeiro em 1844, e realizou uma carreira contínua e de sucesso no teatro lírico e dramático no Brasil.

38 Se sobrevivesse por mais doze anos, talvez Velluti, que residia na rua da Boa Vista, número 1, tivesse encontrado Lima Barreto como vizinho. O escritor se mudou com sua família para uma casa alugada na mesma rua da Boa Vista, hoje rua Elisa de Albuquerque, em 1903. O bairro de Todos os Santos era um típico lugar de classe média baixa, com uma população extensa de portugueses, segundo o censo de 1903, servido e expandido pela linha de trem que se situa até hoje frente à rua. Cf. Schwarcz, 2017.

39 A condessa de Daupiás era Joana Daupiás, prima de seu marido, Pedro Eugénio Daupiás (1818-1900), primeiro visconde e primeiro conde de Daupiás, um rico negociante e industrial de Lisboa. Amantes e apoiadores das artes, o casal amparava artistas portugueses assim como seus ex-operários inválidos e idosos (Portugal, 1904-1915, p. 21-22). O texto que informa sobre a pensão concedida à Velluti diz ainda que a atriz recebeu a ajuda por mais de "uma dezena de anos", e que a condessa era "senhora de reconhecidas virtudes de bondade pela prodigalidade em socorrer os necessitados e desprotegidos da fortuna, em Lisboa" (O Tempo, 18 jul. 1891, p.2).
} 
Um outro obituário surgiu na crônica dominical de Artur Azevedo, que assinava "Eloy, o herói" no folhetim do Diário de Notícias. De tom relativamente sarcástico e maldoso, o parágrafo que informava a morte de Velluti talvez seja uma indicação do que ela enfrentou como mulher e artista:

Faleceu também Maria Velluti, boa e simpática velhinha, que tinha sido atriz e literata. Como atriz, não deixou nome; como literata, parecia-me inferior a $\mathrm{C}$. $\mathrm{Cy}$. Entretanto, era uma mulher ilustre: foi amada por Almeida Garret, de quem tinha um filho que lhe fartou de dar desgostos. Acabou paupérrima. (Diário de Notícias, 19 jul. 1891, p.1)

A escritora Corina Coaracy - a "C. Cy" citada no texto de Azevedo - escreveu protestando contra o cronista. Segundo ela, Velluti recebera dele, "depois de morta, a mais cruel das injustiças como artista, o mais duro dos acintes como mãe". Diz Coaracy:

D. Maria Velluti, se não foi um gênio, uma estrela de primeira grandeza no teatro moderno, teve ao menos bastante talento, bastante intuição artística para merecer francos aplausos dos críticos de seu tempo. Como atriz, Maria Velluti teve criações notáveis, e muitos são aqueles que ainda se lembram do modo brilhante por que ela desempenhou o personagem do Duque nas Proezas de Richelieu, um dos mais difíceis travestis que hajam sido escritos, e um papel que artistas como Virginia Dezajet na França, e Lucinda Simões, aqui, julgaram bastante digno e bastante artístico para figurar no repertório de uma atriz de primeira ordem. [...] Como mulher e como mãe sua vida deveria ser respeitada por Eloy, o Herói, o qual sabe que a ninguém é permitido devassar o lar alheio, sob pena de expor o seu a igual dissabor. Se o coração materno de D. Maria Velluti sangrou algumas vezes, não é isso de interesse para o público, e, se a desventura a feriu, fazendo com que um ente que lhe era extremamente caro fosse um desequilibrado, a caridade pelos mortos, já que os vivos pouco a merecem, devera ter poupado a mãe de um insulto póstumo na pessoa de seu filho. (Muzart, 1999, p. 818) (0) $^{40}$

Hoje o seu nome está em uma rua na Vila Inglesa, na cidade de São Paulo, a Travessa Maria Velluti. Entretanto, pouco resta de memória daquela cidade sobre aquela que foi uma esperança de regeneração da vida teatral da capital paulista em meados do século XIX. Na cidade do Rio de Janeiro, muito menos. ${ }^{41}$

Trazer à luz o nome de Maria Velluti, uma artista em várias frentes na produção do teatro brasileiro do século XIX, e, por que não dizer?, uma "intelectual do teatro", também desvela contextos da atividade teatral e das produções, de artistas e públicos. No index de mulheres da história do teatro brasileiro seu nome não deve ser esquecido.

\footnotetext{
40 O texto de Corina Coaracy em defesa de Velluti faz parte da coleção de manuscritos do acervo Arquivo-Museu de Literatura Brasileira (AMLB) depositado na Fundação Casa de Rui Barbosa (RJ). Intitulado "Maria Velluti", foi publicado em 1999 na antologia Escritoras Brasileiras do século XIX: uma antologia, volume 1, organizado por Zahidé Lupinacci Muzart. Não há referências, até o momento, de que o texto chegou a ser publicado em periódicos no ano de falecimento de Velluti. Cf. Vasconcellos, 1999; Muzart, 1999.

41 Apesar desse reconhecimento, precisamos destacar alguns trabalhos recentes que fornecem dados sobre Maria Velluti quando tratam de temas específicos sobre o período e lugares onde ela atuou: E. S. Silva. A Dramaturgia Portuguesa nos Palcos Paulistanos: 1864 a 1898 (Tese). 307 p. Doutorado em Literatura Portuguesa. Faculdade de Filosofia, Letras e Ciências Humanas. Universidade de São Paulo, São Paulo, 2008. J. S. Mendes. Crônica do teatro ludovicense em meados do século XIX (1852-1867): arte, negócio e entretenimento (Dissertação). 195 p. Escola de Comunicações e Artes, Universidade de São Paulo, São Paulo, 2014. O trabalho que se detém concentradamente sobre o nome de Maria Velluti, fazendo um levantamento sobre sua atuação como tradutora, é uma comunicação apresentada por Bruna Feola Monteiro, orientada pela Prof. ${ }^{a}$ Dr. ${ }^{a}$ Orna Messer Levin, no âmbito do projeto Circulação Transatlântica dos Impressos - a globalização da cultura no século XIX, do Instituto de Estudos da Linguagem da UNICAMP: B. F. Monteiro. Tradutora e atriz: Maria Velluti além dos palcos. $8^{\circ}$ Colóquio do PPLB - 450 anos de portugueses no Rio de Janeiro. Real Gabinete Português de Leitura, Rio de Janeiro, agosto 2016. Disponível em http://rgpl.mygead.com/OPAC/Register/Index/4a5277a7-b1bd-4fb0-9e2a-5749a11378a1 Acesso em ago. 2018.
} 


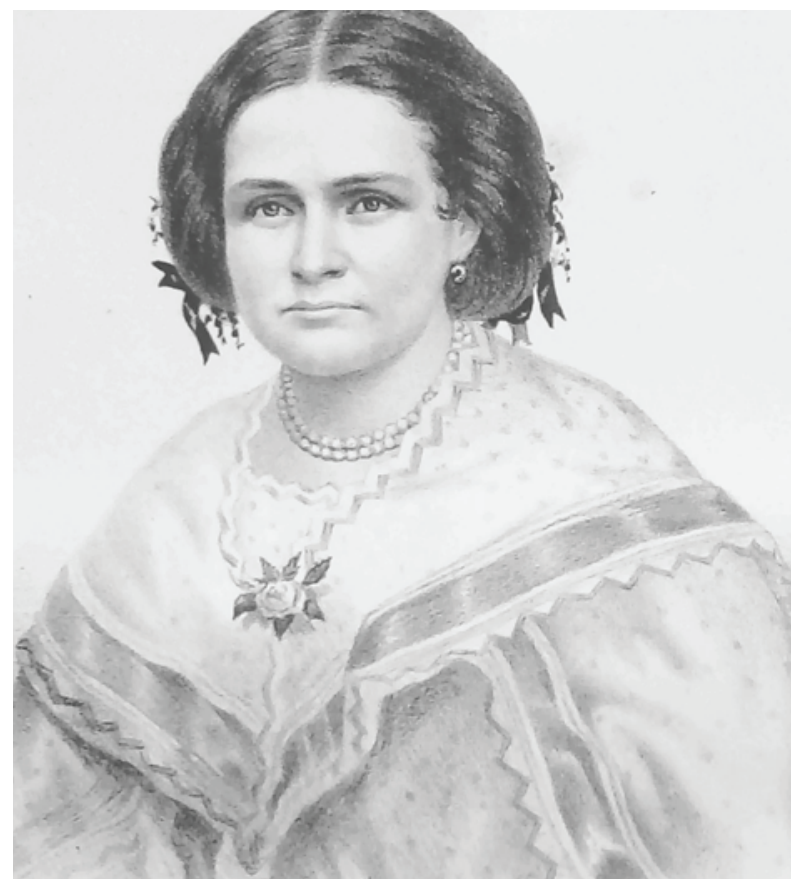

Imagem 10: Maria Velluti em litografia que acompanha a publicação de sua tradução para o português da comédia francesa $A$ viúva das camélias: cenas da vida parisiense (La veuve au camélia: scènes de la vie parisienne) de Paul Siraudin, Alfred Delacour e Lambert-Thiboust. A comédia estreou em Paris no Théâtre du Palais-Royal, em 1857, e foi representada em 1858, no Teatro Ginásio, Rio de Janeiro, com elenco composto por Josephina Miró, Júlia Heller, Martins e Torquato (Correio Mercantil, 01/09/1858). A publicação é de 1859, e talvez seja esse o ano da imagem de Velluti retratada na litografia assinada por "A. de Pinho Lithographia" e "Lithographia Imperial de Ed. Rensburg". Fonte: A viúva das camélias; cenas da vida parisiense. Comédia em 1 acto. Traduzida do francês por D. Maria Velluti. Rio de Janeiro: Typographia e Livraria de Bernardo Xavier Pinto de Sousa, 1859. Acervo da Fundação Biblioteca Nacional do Rio de Janeiro.

\section{Referências}

ANDRADE, Ayres de. Francisco Manuel da Silva e seu tempo (1808-1865). v. 2. Rio de Janeiro: Secretaria de Educação e Cultura, 1967.

ANICET-BOURGEOIS, Auguste; BARRIÈRE, Theodore. A vida de uma actriz. Drama em 5 atos e oito quadros por M. M. Aniceto Bourgeois e Theodoro Barrière. Traduzido do francês por D. Maria Velluti. Rio de Janeiro: Typ. e Livraria de Bernardo Xavier Pinto de Souza, 1859.

AZEVEDO, Elizabeth. R. Ensaiadores na cena brasileira do século XIX e XX. Revista Sala Preta. Vol. 15. no 1, 2015, p. 106.

FARIA, João Roberto. Machado de Assis: do teatro. São Paulo: Perspectiva, 2008.

FARIA, João Roberto. O Teatro Realista no Brasil: 1855-1865. São Paulo: Perspectiva/Edusp, 1993.

GUINSBURG, J. et al. Dicionário do teatro brasileiro: temas, formas e conceitos. $2^{\mathrm{a}}$ ed. São Paulo: Perspectiva/Edições SESC-SP, 2009.

MACHADO DE ASSIS, J. M. Notícia da Literatura Brasileira. Instinto de Nacionalidade. O Novo Mundo. New York, 24/03/1873. In: FARIA, J. R. Machado de Assis: do teatro. São Paulo: Perspectiva, 2008, p. 531-532. 
MENDES, Jacqueline Silva. Crônica do teatro ludovicense em meados do século XIX (1852-1867): arte, negócio e entretenimento. Dissertação (Mestrado). 195 p. Programa de Pós-Graduação em Artes Cênicas. Escola de Comunicações e Artes. Universidade de São Paulo, São Paulo, 2014.

MONTEIRO, Bruna Feola. Tradutora e atriz: Maria Velluti além dos palcos. 8 Colóquio do PPLB - 450 anos de portugueses no Rio de Janeiro. Real Gabinete Português de Leitura, Rio de Janeiro, agosto 2016. Disponível em http://rgpl.mygead.com/OPAC/ Register/Index/4a5277a7-b1bd-4fb0-9e2a-5749a11378a1 Acesso em ago. 2018.

MUZART, Zahidé Lupinacci (org.). Escritoras brasileiras do século XIX: Antologia, vol. 1. Florianópolis: Editora Mulheres; Santa Cruz do Sul: EDUNISC, 1999.

PORTUGAL. Dicionário Histórico, Corográfico, Heráldico, Biográfico, Bibliográfico, Numismático e Artístico, vol. III. Lisboa: João Romano Torres Editor, 1904-1915.

SANTOS, J. E. dos. Exemplo de cidadão. Tribuna de Petrópolis, 23/09/2016. Disponível em http://e-tribuna.com.br/ler/exemplo-de-cidadao/5037 Acesso em ago. 2016.

SCHWARCZ, Lilia Moritz. Da minha janela vejo o mundo passar: Lima Barreto, o centro e os subúrbios. Estud. av., São Paulo, v. 31, n. 91, p. 123-142, Dez. 2017. Disponível em http://www.scielo.br/scielo.php?script=sci_arttext\&pid=S0103-40142017000300123\&lng=en\&nrm=iso. Acesso em mar. 2019.

SILVA, Edson Santos. A Dramaturgia Portuguesa nos Palcos Paulistanos: 1864 a 1898. Tese (Doutorado). 307p. Doutorado em Literatura Portuguesa. Faculdade de Filosofia, Letras e Ciências Humanas. Universidade de São Paulo, São Paulo, 2008.

SILVA, Innocencio Francisco da. Dicionário Biobibliographico Português. Estudos de Innocencio Francisco da Silva aplicáveis a Portugal e ao Brasil. Tomo quinto. Lisboa: Imprensa Nacional, 1860.

SOUSA BASTOS, Antônio de. Carteira do Artista. Lisboa: Antiga Casa Bertrand-José Bastos, 1898.

SOUZA, Silvia Cristina Martins de. As noites do Ginásio: teatro e tensões culturais na Corte (1832-1868). São Paulo: Unicamp/Cecult, 2002.

VASCONCELLOS, Eliane. Corina Coaraci. RUBI - Repositório Rui Barbosa de informações culturais. Rio de Janeiro: Fundação Casa de Rui Barbosa, 1999. Disponível em http://www.casaruibarbosa.gov.br/dados/DOC/artigos/o-z/FCRB_ElianeVasconcellos_Corina_Coaraci.pdf Acesso em jan. 2019.

ZAMITH, Rosa Maria Barbosa. A dança da quadrilha: da partitura aos espaços festivos: música, dança e sociabilidade no Rio de Janeiro oitocentista. Rio de Janeiro: E-papers, 2011. 


\section{Periódicos}

A Nação, 1873.

ALMANAK administrativo, mercantil e industrial da Corte e província do Rio de Janeiro para o ano de 1852. Rio de Janeiro: Laemmert \& C., 1851.

ALMANAK administrativo, mercantil e industrial da Corte e província do Rio de Janeiro para o ano de 1853. Rio de Janeiro: Laemmert \& C., 1852.

A Vida Fluminense, 1868.

Brazil-Theatro. Repertório dramático de autores nacionaes e estrangeiros. Fascículo 02. Collectanea Dr Pires de Almeida, Rio de Janeiro, s.e., 1903-1904.

Correio Mercantil, 1851-1868.

Correio Paulistano, 1862-1865.

Diário de Notícias, 1891.

Diário do Rio de Janeiro, 1855-1877.

Gazeta da Tarde, 1881-1882.

Jornal do Commercio, 1847-1879.

Jornal do Recife, 1868-1869.

Monitor Campista, 1877.

O Commercial, 1870.

O Globo, 1875.

O Mosquito, 1873.

O Tempo, 1891.

Revista llustrada, 1881.

Recebido em: 30/09/2018

Aprovado em: 16/02/2019 